\title{
The Impacts of Decentralisation on Forests and Forest-Dependent Communities in Malinau District, East Kalimantan
}

Christopher Barr

Eva Wollenberg

Godwin Limberg

Njau Anau

Ramses Iwan

I Made Sudana

Moira Moeliono

Tony Djogo 


\section{CIFOR REPORTS ON DECENTRALISATION AND FORESTS IN INDONESIA}

\section{Synthesis of Major Findings}

Barr, C. and Resosudarmo, I.A.P. 2002. Decentralisation of forest administration in Indonesia: Implications for forest sustainability, community livelihoods, and economic development. Center for International Forestry Research, Bogor, Indonesia.

\section{District and Provincial Case Studies}

Case Study 1. McCarthy, J.F. 2001. Decentralisation, local communities and forest management in Barito Selatan District, Central Kalimantan. Center for International Forestry Research, Bogor, Indonesia.

Case Study 2. McCarthy, J.F. 2001. Decentralisation and forest management in Kapuas District, Central Kalimantan. Center for International Forestry Research, Bogor, Indonesia.

Case Study 3. Barr, C., Wollenberg, E., Limberg, G., Anau, N., Iwan, R., Sudana, I.M., Moeliono, M., and Djogo, T. 2001. The impacts of decentralisation on forests and forestdependent communities in Malinau District, East Kalimantan. Center for International Forestry Research, Bogor, Indonesia.

Case Study 4. Casson, A. 2001. Decentralisation of policies affecting forests and estate crops in Kutai Barat District, East Kalimantan. Center for International Forestry Research, Bogor, Indonesia.

Case Study 5. Casson, A. 2001. Decentralisation of policymaking and administration of policies affecting forests and estate crops in Kotawaringin Timur District. Central Kalimantan. Center for International Forestry Research, Bogor, Indonesia.

Case Studies 6 and 7. Potter, L. and Badcock, S. 2001. The effects of Indonesia's decentralisation on forests and estate crops: Case study of Riau province, the original districts of Kampar and Indragiri Hulu. Center for International Forestry Research, Bogor, Indonesia.

Case Study 8. Soetarto, E., Sitorus, M.T.F. and Napiri, Y. 2001. Decentralisation of administration, policy making and forest management in West Kalimantan. Center for International Forestry Research, Bogor, Indonesia.

Case Study 9. Obidzinski, K. and Barr, C. 2002. The effects of decentralisation on forests and forest Industries in Berau District, East Kalimantan. Center for International Forestry Research, Bogor, Indonesia. 


\title{
The Impacts of Decentralisation on Forests and Forest-Dependent Communities in Malinau District, East Kalimantan
}

\author{
Christopher Barr \\ Eva Wollenberg \\ Godwin Limberg \\ Njau Anau \\ Ramses Iwan \\ I Made Sudana \\ Moira Moeliono \\ Tony Djogo
}


(C) 2001 by Center for International Forestry Research All rights reserved. Published in 2001

Printed by SMK Grafika Desa Putera, Indonesia

\section{ISBN 979-8764-81-1}

\section{Published by}

Center for International Forestry Research

Mailing address: P.O. Box 6596 JKPWB, Jakarta 10065, Indonesia

Office address: Jl. CIFOR, Situ Gede, Sindang Barang, Bogor Barat 16680, Indonesia

Tel.: +62 (251) 622622; Fax: +62 (251) 622100

E-mail: cifor@cgiar.org

Web site: http://www.cifor.cgiar.org 


\section{Decentralisation and Forests in Indonesia: An Overview of the Study}

ince early 2000, the Center for International Forestry Research (CIFOR) has conducted research on the decentralisation of forest administration and policies affecting forests in Indonesia. This project has sought to document the real and anticipated impacts of decentralisation on forest management, forest community livelihoods, and economic development at the provincial and district levels. During the initial phase of this research, CIFOR conducted case studies in nine kabupaten or districts, in four provinces: Riau, East Kalimantan, Central Kalimantan, and West Kalimantan. These case studies were carried out in 2000, with follow up visits to some districts conducted in early 2001. As such, the findings presented in the present report and the companion case studies reflect the conditions and processes that existed in the study districts during the initial phase of Indonesia's decentralisation process.

The following reports have been produced by this project. The first of these represents a synthesis of the major findings from the nine case studies, accompanied by a historical analysis of forest administration and forestry sector development in Indonesia, and a discussion of the origins and legal-regulatory basis of the nation's ongoing decentralisation process. Each of the nine case studies is published as a separate report (with the exception of the study districts in Riau, which have been combined) in order to make the information contained therein more readily accessible to decision-makers involved in the decentralisation process. It is hoped that readers of the case studies will refer to the synthesis report in order to situate the specific case study findings in a broader historical and policy context.

During 2002, CIFOR will publish additional case studies from research on decentralisation and forests in West Kalimantan, South Sulawesi and Irian Jaya. CIFOR also plans to carry out follow-up research at several of the original case study districts, and will publish periodic findings from the sites.

\section{Acknowledgements and Disclaimer}

CIFOR gratefully acknowledges the financial support of the Australian Center for International Agricultural Research (ACIAR) and the United Kingdom's Department for International Development (DFID). Partial support was also provided by the International Fund for Agricultural Development (IFAD) and the International Tropical Timber Organization (ITTO) in partnership with the Ministry of Forestry, Indonesia through Project PD 12/97 Rev. I (F) Forest, Science and Sustainability: The Bulungan Model Forest. The opinions expressed in this report are the views of the author(s) and do not necessarily represent the official policy of CIFOR. These opinions, likewise, do not represent the official policy of ACIAR or DFID or any other organization involved in funding, conducting or disseminating this study. 


\section{Editor's Overview of Indonesia's Decentralisation Process Preface}

Since late-1998, Indonesia has undergone a process of rapid and far-reaching decentralisation. With this process, considerable degrees of administrative and regulatory authority have been transferred from the national government in Jakarta to the country's provincial and district governments. This transfer of authority has occurred across broad segments of the nation's economy and has sharply redefined the roles and responsibilities of government agencies at each level of the nation's administrative structure. With the locus of decision-making shifting decisively away from the national government, Indonesia's ongoing decentralisation process marks a dramatic break from the highly-centralised system of governance that characterized Suharto's New Order regime during the period 1966-1998.

To a significant extent, the process of decentralisation now occurring in Indonesia has been driven by the demands of provincial and district governments whose jurisdictions are rich in timber, petroleum, and other natural resources. Officials from resource-rich regions have long complained that the vast majority of the benefits from these assets have flowed away from their regions to the national government and to private sector companies closely associated with decision-makers in Jakarta. While the New Order government kept a tight lid on calls for greater regional autonomy and regional control over natural resource revenues, the post-Suharto government has not been able to ignore these demands. On the contrary, since 1998 the country's senior leadership has recognised that its ability to maintain Indonesia's integrity as a nation may ultimately depend on its capacity to strike a more equitable balance of power between the national government, on the one hand, and the provincial and district governments, on the other.

Over the last three years, the national government has issued several important pieces of legislation aimed at transferring authority to the provincial and district governments, and at allowing resource-rich regions to retain a larger share of the fiscal revenues generated within their jurisdictions. The most significant of these have been Law 22 on Regional Governance and Law 25 on Fiscal Balancing, both of which were issued in May 1999. Together, these laws provide the legal basis for regional autonomy, laying out a broad framework for the decentralisation of administrative and regulatory authority primarily to the district level. These laws have been supported by a variety of implementing regulations and sector-specific decentralisation laws, including Law 41 of 1999, a revised version of Indonesia's Basic Forestry Law, which outlines the division of administrative authority in the forestry sector under regional autonomy.

In many parts of Indonesia, provincial and district officials acting in the spirit of regional autonomy have instituted reforms that extend well beyond the authority granted to them under the national government's decentralisation laws and regulations. Indeed, the formal decentralisation process has been 
driven, to a significant degree, not by policy decisions made at the national level but, rather, by decisions made by provincial and district level actors. This process has often been ad hoc in nature, with national policymakers frequently finding themselves in the position of having to react to fast-moving changes that have occurred in the provinces and districts. Far from being a well-planned and carefully-managed exercise in bureaucratic reorganization, the implementation of regional autonomy in Indonesia has been characterized by intense struggles among the different levels of government, each of which represents a competing set of political and economic interests. In this way, regional autonomy has stretched well beyond the formal decentralisation of administrative and regulatory authority; in practice, it also involves a significant, if largely informal and unplanned, devolution of power from the national government to its provincial and district-level counterparts.

The formal and informal processes of decentralisation have been accompanied by a wide-ranging set of governance and economic reforms, collectively known as reformasi, that are associated with Indonesia's transition away from Suharto's New Order regime. Broadly defined, reformasi refers to the transformation and dismantling of the policies, practices, and institutional structures through which the New Order leadership and a handful of well-connected conglomerates controlled the political and economic life of the country prior to Suharto's resignation in May 1998. While significant elements of the reformasi agenda coincide with the changes occurring under regional autonomy, these reform processes are also quite distinct. Whereas reformasi refers to a shift away from the constellation of interests and power structures that have supported a particular regime, decentralisation and regional autonomy refer to the transfer of authority from the national government to Indonesia's provincial and district governments.

\section{Decentralisation of Forest Administration}

The formal and informal processes of decentralisation that are now occurring in Indonesia have far-reaching implications for forest management and for the livelihoods of communities living in and around forested areas. On the positive side, experience from other countries suggests that decentralized systems of forest management often lead to more sustainable and equitable use of these resources, as decision-makers are physically located closer to where their policies will be implemented (Conyers 1981; Rondinelli, Nellis, and Cheema 1983). This proximity often brings with it improved understanding of the specific biophysical, social, and institutional conditions influencing forest management at the field level; better capacity to monitor the activities of forest user groups; and greater access to local knowledge about the management and utilization of forest resources - which are sometimes highly specific to particular social groups and/or ecosystems (Carney 1995).

In addition, decentralized forest administration often allows for greater participation on the part of forest communities in policy decision-making processes, and more direct accountability of policymakers to peoples whose livelihoods depend on forests (Brandon and Wells 1992). Decentralisation also frequently implies a more equitable 
distribution of benefits from forest resources, as local communities and governments in forested regions are able to secure a greater portion of revenues from the extraction of timber and other forest products (Ascher 1995; Ostrom 1990).

In addition to providing opportunities for expanded equity and improved forest management, however, decentralisation also carries significant risks. In many countries, national governments have decentralized without first creating the necessary institutional capacity at the provincial or district levels to administer forests effectively (Rivera 1996). Often, national governments assign tasks to provincial and district governments without giving them adequate resources for carrying out these tasks. Most provincial and district governments lack essential technical skills and must look to other entities for advice, training, and technical information. In cases where local elites have been strong and/or traditionally marginalized groups have been unable to organize themselves, decentralisation has often strengthened pre-existing power relations, rather than promoting democratic decision-making processes (Utting 1993). Finally, even when elite groups do not dominate provincial and district governments, it is often that case that these governments have little interest in sustainable forest management.

\section{Indonesia's Forestry Sector}

The manner in which decentralisation affects forest management, community livelihoods, and economic development is of particular significance in Indonesia due to the scale and importance of the country's forest resources. Indonesia has the world's third largest tract of tropical forests, surpassed in area only by those of Brazil and Congo. In 1997, the country's total forest cover was officially estimated to be 100 million hectares (MOFEC, cited in World Bank 2001). It has been conservatively estimated that at least 20 million people depend on Indonesia's forests for the bulk of their livelihoods (Sunderlin, et al. 2000). Over the last three decades, the national government has allocated over 60 million hectares of forest to commercial logging companies, and Indonesia's forestry sector industries have long ranked second only to petroleum in terms of their contribution to GNP (Barr 2001). The forestry sector currently generates approximately US\$ 7 billion in annual revenues.

Well before the country's ongoing decentralisation process began in late-1998, Indonesia's forestry sector had entered a period of crisis. From the mid-1980s onward, deforestation is estimated to have occurred at a pace of 1.6 million hectares per year (Toha 2000). A major factor driving this high level of deforestation and associated forest degradation has been overcapacity in the nation's wood processing industries. Through the mid-1990s, Indonesia's sawnwood, plywood, and pulp industries are collectively estimated to have consumed 60-80 million cubic meters $\left(\mathrm{m}^{3}\right)$ of wood per year (Barr 2001; Scotland et al. 1999). Log consumption on this scale has stood well above the Indonesian government's own widely-cited sustainable timber harvest threshold of 25 million $\mathrm{m}^{3}$ per year. Moreover, with few effective regulatory structures in Indonesia's forestry sector, domestic demand for timber has resulted in large volumes of wood being harvested from illegal sources (ITFMP 1999). At the same time, a decline in the nation's HPH timber concession system, coupled with rapid expansion 
in oil palm and other forms of agroindustrial plantations, has meant that a growing portion of the nation's wood supply has been obtained through clearing of natural forest rather than selective harvesting at multiple-rotation timber concessions (Barr 2001).

\section{Scope and Methods of the Present Study}

The present study examines the preliminary effects of decentralisation on forests and estate crops in Malinau district, East Kalimantan. It is one of nine district level case studies carried out during 2000 and early 2001 by the Center for International Forestry Research (CIFOR) in four provinces: Riau, East Kalimantan, Central Kalimantan, and West Kalimantan. The findings presented in these studies reflect the conditions and processes that existed in the study districts during the initial phase of Indonesia's decentralisation process.

Each of the case studies used a rapid appraisal methodology for gathering data at the district and provincial levels. For each case study, preliminary visits were made to the district and provincial capitals to establish initial contacts and to identify key issues. Second visits for data gathering were then carried out for periods of 10-14 days in each district, with shorter amounts of time in the provincial capitals. The collection of primary data involved semi-structured interviews with key informants, including: government officials; forest industry actors; members of communities living in and around forests; political party representatives; officers from the regional military and police force; informal district leaders; representatives from nongovernmental organizations (NGOs); university researchers; and individuals involved with donor agencies and development projects. Data collection also involved the review of primary and secondary documents, including: district and provincial laws and regulations; government statistics; regional news media articles; industry publications; research studies; and reports prepared by NGOs and donor agencies.

Each of these case studies is structured to focus on processes that have occurred at the district and, to a lesser extent, the provincial levels. To avoid repetition, more general information on the history of forest administration and forestry sector development in Indonesia, as well as significant national policy and legal-regulatory reforms associated with decentralisation, has been placed in an accompanying report which synthesizes the project's major findings (see Barr and Resosudarmo 2001). Readers are encouraged to review the case studies in conjunction with this synthesis in order to appreciate the broader historical and policy contexts within which the district and provincial decentralisation processes are now occurring.

Christopher Barr and Ida Aju Pradnja Resosudarmo

Bogor, Indonesia 


\section{Glossary}

Adat

APBD

APHI

BAPPEDA

BKPM

Bupati

Camat

CDK

CIFOR

$\mathrm{CV}$

Daerah Istimewa

Daerah Swapraja

Dinas Kehutanan Kabupaten

Dinas Kehutanan Propinsi

Dispenda

DPRD

DR

$\mathrm{HPH}$

HPHH

IHPH

IMF

IPK

IPPK

Kabupaten

Kawasan Hutan
Customary rights or practices

Anggaran Pendapatan dan Belanja Daerah, District Budget

Asosiasi Pengusaha Hutan Indonesia, Indonesian Forest Concession Holders Association

Badan Perencanaan Pembangunan Daerah, Regional Development Planning Agency

Badan Koordinasi Penanaman Modal, Capital Investment Coordinating Board

District Head

Head of subdistrict

Cabang Dinas Kehutanan, Branch Office of the Provincial Forestry Service

Center for International Forestry Research

Commanditaire Vennootschap, Limited Partnerships

Special Region

Autonomous Region

District Forestry Service

Provincial Forest Service

Dinas Pendapatan Daerah, District Revenue Office

Dewan Perwakilan Rakyat Daerah, Provincial or District Legislative Assembly

Dana Reboisasi, Reforestation Fund

Hak Pengusahaan Hutan, Commercial Forestry Concessions

Hak Pemungutan Hasil Hutan, Forest Product Harvest Concession

Iuran Hak Pengusahaan Hutan, Timber Concession Royalty

International Monetary Fund

Izin Pemanfaatan Kayu, Timber Clearance Permit

Izin Pemungutan dan Pemanfaatan Kayu, Timber Extraction and Utilization Permits

District

Forest Estate 
Kecamatan

Kelurahan

Kepala Adat

Kepala Desa

Kotamadya

MOU

NGO

NRM

PAD

Pajak Penghasilan

PPN

PBB

Pemda

Perda

PP

PSDH

PT

Putera daerah

SBU

SKSHH

TGHK

TPTI

UU

WWF
Subdistrict

Village

Adat Head

Village Head

Municipality

Memorandum of Understanding

Non Governmental Organization

Natural Resources Program

Pendapatan Asli Daerah, Regionally Generated Revenues, often refers to revenues that district governments obtain from sources within their districts

Income Tax

Pajak Pertambahan Nilai, Ad Valorem Tax

Pajak Bumi dan Bangunan, Land and Building Tax

Pemerintah Daerah, District or Provincial Government

Peraturan Daerah, Regional Government Regulation

Peraturan Pemerintah, Government Regulation

Provisi Sumber Daya Hutan, Forest Resource Rent Provision

Perseroan Terbatas, Limited Liability Companies

Child of the region, or 'local son'

Strategic Business Unit

Surat Keterangan Sahnya Hasil Hutan, Permit to Transport Timber and Other Forest Products

Tata Guna Hutan Kesepakatan, Forest Land Use Concensus

Tebang Pilih Tanaman Indonesia, Indonesian Selective Cutting and Planting System

Undang-undang, Law

Worldwide Fund for Nature 


\section{Table of Contents}

Decentralisation and Forest in Indonesia: An Overview of the Study iii

Editor's Preface

Glossary viii

Abstract xii

1. Background 1

1.1 Methods 2

1.2 Overview of Kabupaten Malinau 2

1.3 Forest Resources Base and Timber Production 5

2. Decentralisation in Malinau 8

2.1 Establishment of a New District Government and

Regulatory Regime 8

2.2 District Revenue Generation 9

2.2.1 Securing an Increased Share of HPH Revenues $\quad 10$

2.2.2 Generating New Investment 12

2.3 Allocation of IPPK Forest Conversion Permits 13

2.3.1 New Pressures on Forests 14

2.3.2 Timber Profits for New Actors 18

2.4. Overlap of IPPK Conversion Areas and HPH Timber Concessions 19

2.4.1 Response by Inhutani's and Other HPH-Holders $\quad 22$

2.5 Community Claims to Land and Forest Rights 25

2.5.1 Under the New Order Regime 25

2.5.2 Adat Unleashed 26

2.5.3 Defining Adat Claims 27

2.5.4 IPPK Benefits for Local Communities 30

2.5.5 Has Space Been Created for the Communities? 31

2.6 Coordinating Land Use 33

2.6.1 District Spatial Planning 34

2.6.2 Village Land Use Planning 36

3. Conclusion 38

3.1 Rapidity of Change 39

3.2 Focus on Short-term Income Gains 39

3.3 The Increasing Power of Existing Political and Ethnic
Coalitions

3.4 Decentralisation as Democratisation? 40

4. Endnotes 42

5. References 47 


\section{Abstract}

Malinau District, established through partition in 1999, is the largest district in East Kalimantan, and contains some of its largest tracts of forest. With decentralization, the district has sought to generate revenues from its forests, but these efforts have been handicapped by a concurrent lack of institutional capacities to manage rapid forest exploitation and conflicts over claims. Timber extraction and utilization permits (Izin Pemungutan dan Pemanfaatan Kayu or IPPK) have been the main instrument for revenue generation, with 39 IPPK covering 56,000 ha. expected to generate revenues equivalent to roughly nine times the district's 2000 budget. The IPPKs have enabled local entrepreneurs and communities to gain access to forest land and benefits previously controlled by centrally allocated concessions, however conflict has increased significantly where IPPK's overlapped with concessions and where IPPKs did not fulfill contractual obligations to communities. Overlapping adat or customary-based claims to land have fueled further conflict. While districts now enjoy more control and economic benefits from forests, there is a high risk of reconcentration of power at the district level, especially as government officials lack accountability to villagers and communities still lack secure legal rights to resources. 


\section{BACKGROUND}

Located in the northern corner of East Kalimantan, Malinau officially came into existence as a kabupaten, or district, in October 1999 , following the partition of the expansive kabupaten Bulungan into three districts of somewhat more modest size. Kabupaten Malinau is now the largest of the province's eight districts, encompassing 42,000 square kilometers $\left(\mathrm{km}^{2}\right)$ - an area the size of the Netherlands (Bappeda Tk II 1998). The district has just over 35,000 inhabitants, over half of which are concentrated in and around the town of Malinau, the kabupaten's administrative center (Bappeda Tk II 1998). In contrast to much of East Kalimantan, which has been heavily logged since the early-1970s, Malinau still has extensive forest resources, with 95 percent of the district's land area officially classified as Forest Estate (Kawasan Hutan). Roughly three-quarters of the KayanMentarang National Park, Indonesia's second largest protected area, is located within the district's boundaries.

Indonesia's decentralization and regional autonomy processes have placed considerable pressures on Malinau's fledgling government, like kabupatens elsewhere, to generate new investment in the region and to secure a substantially larger portion of their revenues from local sources (Sekretaris Daerah 2001). Since early-2000, Malinau's administration has taken significant steps in both directions by issuing numerous small-scale forest conversion permits, known as IPPKs (Ijin Pemungutan dan Pemanfaatan Kayu). Many of the IPPKs thus far distributed by the Bupati have been allocated to Malaysian-backed logging companies working in collaboration with Malinau-based timber brokers and forest-dependent communities. The IPPK permits are ostensibly designed to provide royalties to the district government and a range of benefits, including volume-based fees, in-kind contributions, and employment, to the communities. As part of a longer-term strategy, Malinau's kabupaten government is actively seeking to develop roads and other forms of physical infrastructure in order to attract further investment in the forestry, plantations, and mining sectors.

This paper offers a preliminary analysis of the real and anticipated effects of decentralization on the forests and forest-dependent communities in kabupaten Malinau. It examines, in particular, the challenges created by the fact that Malinau's inception as a kabupaten has come at a time when the administrative functions of government are being rapidly decentralized. In the forestry sector, the newly-established district government is in the process of making major land-use decisions before a comprehensive spatial planning process for Malinau has been conducted. There are strong reasons to believe that this could result in landuse decisions that favor rapid forest conversion in the short-term with little concern for the district's long-term timber production and forest conservation needs.

As significantly, Malinau's kabupaten government has thus far allocated numerous IPPK forest conversion licenses before it has 
developed the institutional capacity to adequately regulate the logging companies receiving the permits. There are preliminary indications that some companies may use the IPPK permits to legitimize illegal timber felling in areas that well exceed those assigned to them. Moreover, the structure of many companies' agreements with local communities offers little guarantee that the new investors will follow through with promises to plant agricultural cash crops once commerciallyvaluable timber is removed from the forest areas cleared. This raises serious questions regarding the potential impacts of decentralization on both the economic well-being of forest-dependent communities in Malinau and the likelihood of conflicts arising over how the benefits from Malinau's forest resources are distributed.

\subsection{METHODS}

Our analysis is based on observations made in Malinau district since August 1999. We conducted interviews with government officials and timber companies in Kota Malinau for one week in March 2000 and in kota Malinau, Tarakan and Tanjung Selor for three weeks in August - September 2000. We collected information from communities through interviews and direct observation while conducting an action research project on conflict management and participatory mapping of village boundaries with 27 villages of the upper Malinau River watershed. Four to nine staff have been based nearly continuously in local villages since August 1999 and have had the chance to observe the changes brought about by decentralization first hand. We also draw upon observations made from three large workshops that CIFOR has facilitated in the last two years to bring together the multiple stakeholders involved in forest management.

\subsection{OVERVIEW OF KABUPATEN MALINAU}

Prior to its partition in late-1999, the original kabupaten of Bulungan was the second largest district in East Kalimantan, covering nearly
$75,000 \mathrm{~km}^{2}$, or 35 percent of the province's total land area (Bappeda Tk II 1998). As an administrative unit, the kabupaten traces its roots to the Sultanate of Bulungan, which was based in the town of Tanjung Selor at the mouth of the Kayan River (Bappeda Tk II 1998). The Dutch colonial government administered the area indirectly, exacting tribute from the Sultan in the form of rattan, gaharu, aloes, eagle wood, and other forest products that were harvested from the region's vast interior. During the post-colonial period, Bulungan functioned initially as an Autonomous Region (Daerah Swapraja) and in 1955 its status was changed to Special Region (Daerah Istimewa). Bulungan's status was converted to that of a kabupaten in 1960.

By the mid-1990s, the provincial government of East Kalimantan initiated the process of dividing up the kabupatens of Bulungan and Kutai, each of which covered an area roughly equivalent to the province of West Java (Tim Peneliti 1999). The official rationale for this partition was to improve the capacity of the kabupaten governments to administer the areas within their jurisdictions and to provide essential services to a broader spectrum of their respective populations. In Bulungan, it was particularly noted that much of the district's economic growth and infrastructural development had occurred in lowland and coastal areas, without extending to upland areas in the interior (Tim Peneliti 1999). Some observers have also speculated that the provincial and district government's unstated rationale for partitioning Bulungan was to facilitate accelerated extraction of the region's rich forest and mineral resources.

The division of the original kabupaten Bulungan in late-1999 resulted in the creation of three new districts: Bulungan, Malinau, and Nunukan. Postpartition Bulungan encompasses an area covering the entire lower coastline of the original district, while Nunukan covers the northern coastline and border with the East Malaysian state of Sabah. Malinau is land-locked in the region's interior and stretches along much of the original district's western border with Sarawak. Of the three new kabupaten, Malinau encompasses by far the 
Map 1. Malinau District, East Kalimantan

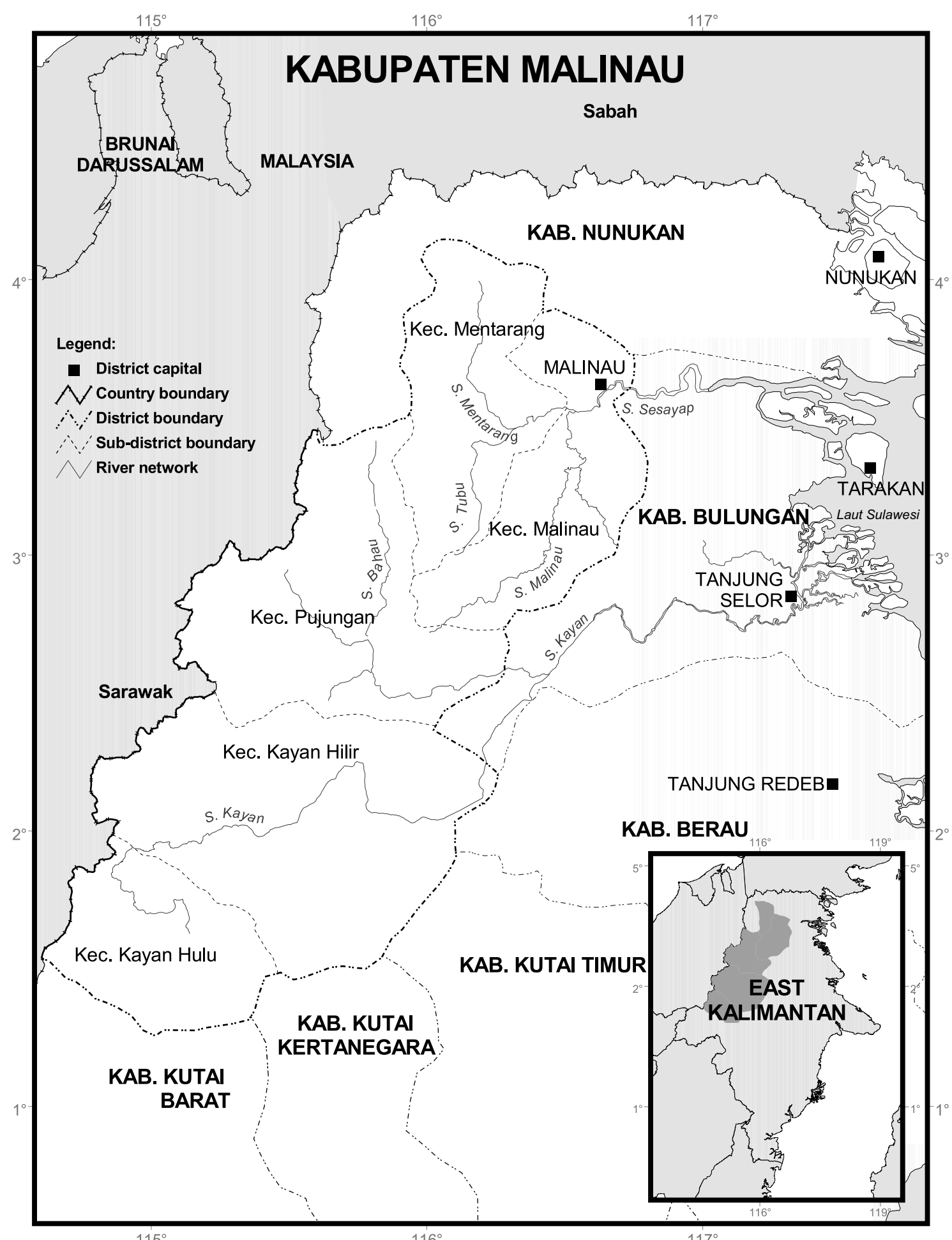


largest area, covering over $42,000 \mathrm{~km}^{2}$, compared to roughly 18,000 and $13,000 \mathrm{~km}^{2}$ for Nunukan and Bulungan, respectively (see Table 1). Malinau's estimated population is just over 35,000 people, or less than one-half the population of either Bulungan or Nunukan.

Administratively, kabupaten Malinau is organized into five kecamatan, or subdistricts: Malinau; Mentarang; Pujungan; Kayan Hilir; and Kayan Hulu. Approximately 20,000 people, or 60 percent of the district's total population, live in kecamatan Malinau, where the district's administrative center is located (see Table 2). There, the population is composed of a diverse mix of ethnic groups, dominated by the indigenous Lundaye/Putuk, Punan, and Tidung and with significant numbers of Bugis, Makasarese and Javanese migrants. The other subdistricts each have small numbers of inhabitants spread over large areas, with population densities of less than 1.0 person per $\mathrm{km}^{2}$. The vast majority of the populace in these kecamatan are indigenous ethnic groups whose livelihoods are based on subsistence agriculture and collection of nontimber forest products. The major ethnic groups inhabiting Malinau's five kecamatan are presented in Table 2.

Much of the area within kabupaten Malinau's jurisdiction is characterized by heavily forested, mountainous terrain. Although a paved road from Bulungan's capital of Tanjung Selor to the town of Malinau is near completion, channels for ground transport through much of the rest of the district are limited to unpaved logging roads. In many of the more rugged or remote parts of the district, even these are non-existent. Historically, rivers have served as the main arteries for travel and trade in the MalinauBulungan region. Indeed, portions of kabupaten Malinau are traversed by five major river systems: the Kayan $(576 \mathrm{~km})$; Bahau $(322 \mathrm{~km})$; Sesayap $(278 \mathrm{~km})$; Malinau $(231 \mathrm{~km})$ and Mentarang (176 km) (Bappeda Tk II 1998). The town of Malinau is located at the confluence of the Malinau and Sesayap Rivers, and can be reached by speedboat in four hours from northeast Kalimantan's commercial hub of Tarakan Island.

Table 1. Land Area and Population of new Kabupaten in Post-Partition Bulungan

\begin{tabular}{lcc}
\hline Kabupaten & Land Area $\left.\mathbf{( k m}^{\mathbf{2}}\right)$ & Population \\
\hline Bulungan & 18,010 & 84,761 \\
Malinau & 42,620 & 35,738 \\
Nunukan & 13,841 & 81,472 \\
Total & $\mathbf{7 4 , 4 7 1}$ & $\mathbf{2 0 1 , 9 7 1}$
\end{tabular}

Source: BAPPEDA \& BPS (1998).

Table 2. Land Area, Population, and Ethnic Composition of Kabupaten Malinau's Five Kecamatan

\begin{tabular}{lccl}
\hline Kecamatan & Land Area $\left(\mathbf{k m}^{2}\right)$ & Population & Major Ethnic Groups \\
\hline Malinau & 5,237 & 20,061 & $\begin{array}{l}\text { Punan, Merap, } \\
\text { Kenyah,Berusu } \\
\text { Lundaye/Putuk, }\end{array}$ \\
& & & Tidung,Bugis \\
& & & Lundaye/Putuk, \\
Mentarang & 7,101 & 5,163 & Punan, Abai, Milau \\
& & & Kenyah, Punan \\
Pujungan & 11,551 & 3,253 & Kenyah \\
Kayan Hilir & 12,921 & 1,490 & Kenyah \\
Kayan Hulu & 5,808 & 5,801 & -- \\
Total & $\mathbf{4 2 , 6 1 8}$ & $\mathbf{3 5 , 7 6 8}$ & \\
\hline
\end{tabular}

Source: BAPPEDA Tk I/ Bulungan (1998) 
The administrative challenges posed by Malinau's general lack of physical infrastructure are compounded by the specific manner in which the original kabupaten Bulungan was partitioned. Contrary to the recommendations of a provincial government team commissioned to assess various scenarios for partition, the boundaries of the three new kabupaten were drawn to cut directly across the region's major watersheds (Tim Peneliti 1999). This has resulted in substantial portions of Malinau's populace being physically cut off from the district's administrative center. In order to reach the town of Malinau, the inhabitants of some parts of Kayan Hulu, Kayan Hilir, and Pujungan, for instance, might have to travel several days down either the Kayan or Bahau rivers to Tanjung Selor, the capital of kabupaten Bulungan. ${ }^{1}$ From there, they would have to catch a speedboat up to Tarakan, where they would board a second boat heading up the Sesayap River to Malinau. The logistical difficulties created by the partition of Bulungan are mirrored by the fact that members of particular ethnic groups living along shared watersheds are, in many cases, now separated by the new kabupatens' political-administrative boundaries.

\subsection{FOREST RESOURCE BASE AND TIMBER PRODUCTION}

Approximately 95 percent of kabupaten Malinau's land area is officially classified as
Kawasan Hutan or Forest Estate. Since the early years of the New Order period, forestry activities in the area currently encompassed by Malinau's five subdistricts have been administered by two branch offices of the Provincial Forestry Service (Cabang Dinas Kehutanan or CDK). ${ }^{2}$ CDK Bulungan Tengah, with headquarters in Tarakan, has jurisdiction over five subdistricts, including kecamatan Malinau and Mentarang - which are now part of kabupaten Malinau - as well as Krayan (now in kabupaten Nunukan), Sesayap (kabupaten Bulungan) and Tarakan (now a kota, or municipality) (Dinas Kehutanan 1999). CDK Bulungan Selatan, which is based in Tanjung Selor, has been responsible for administering forestry activities in Malinau's three remaining subdistricts - kecamatan Pujungan, Kayan Hilir, and Kayan Hulu - and in kabupaten Bulungan's subdistricts of Tanjung Palas and Long Peso (Dinas Kehutanan 1999).

In 1999, the total area of Forest Estate administered by CDK Bulungan Tengah and CDK Bulungan Selatan amounted to 1.2 million ha and 3.9 million ha, respectively (Dinas Kehutanan 1999). Together, the two agencies hold jurisdiction over roughly 2.0 million ha classified as either 'Permanent Production Forest' or 'Limited Production Forest'. As Table 3 shows, this represents approximately 20 percent of the area classified as such for all of East Kalimantan, Indonesia's largest timber-

Table 3. Land Area According to TGHK Forest Classification for CDK Bulungan Tengah, CDK Bulungan Selatan, and East Kalimantan, 1999

\begin{tabular}{lcccc}
\hline $\begin{array}{c}\text { Forest } \\
\text { Classification }\end{array}$ & $\begin{array}{c}\text { CDK Bulungan } \\
\text { Tengah (ha) }\end{array}$ & $\begin{array}{c}\text { CDK Bulungan } \\
\text { Selatan (ha) }\end{array}$ & $\begin{array}{c}\text { Total for East } \\
\text { Selatan (ha) }\end{array}$ & $\begin{array}{c}\text { CDK Bul.Tengah } \\
\text { and Bul. Selatan as \% } \\
\text { of East Kalimantan }\end{array}$ \\
\hline Permanent & 285,215 & 827,605 & $5,792,198$ & 0,19 \\
Limited Production & 336,911 & & & \\
Forest & 237,526 & 625,200 & $4,948,640$ & 0,19 \\
Conversion Forest & 166,247 & 746,981 & $4,910,612$ & 0,11 \\
$\begin{array}{l}\text { Protection Forest } \\
\text { Conservation and }\end{array}$ & $\mathbf{7 4 4 , 4 0 1}$ & $3,437,790$ & 0,27 \\
$\begin{array}{l}\text { Recreation Forest } \\
\text { Total }\end{array}$ & $\mathbf{1 , 2 1 0 , 5 2 4}$ & $\mathbf{1 , 4 4 8 , 1 7 3}$ & $2,030,200$ & 0,80 \\
& & $\mathbf{3 , 9 5 6 , 3 6 0}$ & $\mathbf{2 1 , 1 4 4 , 0 0 0}$ & $\mathbf{0 , 3 1}$ \\
\hline
\end{tabular}

Source: Dinas Kehutanan Kalimantan Timur (1999). 
producing province. CDK Bulungan Tengah and CDK Bulungan Selatan also administer over one-half million hectares classified as 'Conversion Forest'. Moreover, the two agencies are responsible for administering some 915,000 ha of 'Protection Forest' and over 1.6 million ha of 'Conservation and Recreation Forest'. In Malinau, most of the area classified as 'Conservation Forest' falls within the vast Kayan-Mentarang National Park, which straddles the district's western border with Sarawak and accounts for 80 percent of East Kalimantan's total parkland.

Commercial logging began in the Bulungan region in the early-1970s, shortly after Soeharto's New Order government opened Indonesia's forestry sector to private investment. Initially, the Directorate General of Forestry in Jakarta allocated only a few large-scale timber concessions (Hak Pengusahaan Hutan or HPH) in that part of East Kalimantan, and these were primarily located in easily accessible areas along navigable rivers. It was not until the timber boom of the late-1970s that the Directorate General of Forestry began distributing HPHs in portions of the region's interior which now fall within Malinau's boundaries. The allocation of new timber concessions in the Malinau area tapered off in the early-1980s as the government phased in a national ban on log exports. However, several large concession-holders entered the area in the late-1980s and early-1990s when Indonesia's plywood exports underwent rapid expansion. By the time Malinau was established as a kabupaten, $11 \mathrm{HPH}$ existed within some portion of the district's territory, though four of these were apparently inactive at that time (see Table 4). ${ }^{3}$

Most of the HPH timber concessions located in Malinau are connected to large forestry conglomerates with ties to national and provincial elites (Dinas Kehutanan 1999). In at least one case - PT Giri Ekawana - the concession is controlled directly by a corporate arm of the Indonesian military. Four of the eleven HPHs that extend into some portion of Malinau's territory, covering over 400,000 ha, are managed by the state-owned forestry enterprises, Inhutani I and II (Dinas Kehutanan 1999). In at least two of these sites, the areas have been assigned to the Inhutani's after concession licenses held by private timber companies have been surrendered or revoked. The Inhutani's have managed substantial portions of the commercially productive areas within these concessions through profit-sharing arrangements with timber contractors.

Cumulative log production targets for six of the seven HPHs known to be active in kabupaten Malinau amounted to $330,000 \mathrm{~m}^{3}$ in $1997 / 98$ (Kanwil Kaltim 1998). It is possible that actual

Table 4. HPH Timber Concessions Located in Kabupaten Malinau, 1999

\begin{tabular}{|c|c|c|c|c|}
\hline Company & Group & $\begin{array}{l}\text { Year } \\
\text { ocated }\end{array}$ & Area (ha) & $\begin{array}{l}\qquad 1998 / 99 \\
\text { Production Target }\left(\mathrm{m}^{3}\right)\end{array}$ \\
\hline PT Essam Timber & Kalimanis & 1992 & 355,800 & 0 \\
\hline PT Intracawood (2 units) & Inhutani I & 1976 & 250,000 & 160,876 \\
\hline PT Susukan Agung (4 units) & Alas Kusuma & 1989 & 246,000 & 71,811 \\
\hline PT Gama Mula Raya & Kayu Lapis Indonesia & 1979 & 197,000 & 10,231 \\
\hline PT Rangga Kesuma (3 units) & Segara & 1988 & 112,000 & 0 \\
\hline PT Giri Ekawana & Military & 1992 & 110,500 & 0 \\
\hline PT Inhutani II (Genwood) & Inhutani II & 1994 & 99,100 & 0 \\
\hline PT Meranti Sakti II & Sumber Mas & 1978 & 57,500 & 37,046 \\
\hline PT Inhutani II (Malinau) & Inhutani II & 1991 & 48,300 & 25,444 \\
\hline PT Sarana Trirasa Bhakti & Roda Mas & 1990 & 41,000 & 24,630 \\
\hline PT Inhutani I (ex-Royindo) & Inhutani I & & & n.a. \\
\hline Total & & & & 330,038 \\
\hline
\end{tabular}

Source: Dinas Kehutanan Kalimantan Timur 1999. 
timber harvests were considerably higher than this, as many concession-holders and timber contractors operating in the region are believed to regularly under-report the volumes of logs they harvest. Virtually all of the logs harvested within Malinau's boundaries are transported out of the district for processing, as Malinau itself has no significant wood-based industries (Kanwil Kaltim 1998). (Until recently, the kabupaten had only one sawmill, located across the river from the town of Malinau; now it reportedly has three $)^{4}$. A substantial portion of these logs are processed in Tarakan, which has two plywood and blockboard mills, six sawmills, and three moulding facilities (Kanwil Kaltim 1998). Logs from Malinau are also shipped to processing facilities in other parts of Kalimantan and in Java.
In addition to formal timber extraction on the part of HPH-holders, Malinau's forests have also supported a thriving trade in illegallyharvested logs. Much of the illegal logging that occurs in Malinau and other parts of northeast Kalimantan is reportedly coordinated by timber syndicates based in Tanjung Selor and Tarakan. These syndicates are said to work quite closely with regional units of Indonesia's military and national police force. The syndicates also reportedly have strong ties to Malaysian timber buyers. Indeed, over the past several years, significant volumes of illegally-harvested logs from Malinau and its neighboring districts have been smuggled across the border to Sabah (Suara Kaltim 2000a). 


\section{DECENTRALISATION IN MALINAU}

\subsection{ESTABLISHMENT OF A NEW DISTRICT GOVERNMENT AND REGULATORY REGIME}

The specific effects of decentralization and regional autonomy in Malinau have, thus far, been heavily shaped by the fact that the district only came into existence in late-1999. As such, Malinau's kabupaten government is still in the process of developing its core administrative and regulatory structures, and its institutional capacity in many areas remains quite limited. For the first 18 months following its inception, Malinau was administered by a provisional Bupati appointed by the Bupati of kabupaten Bulungan. Malinau had no District Legislative Assembly (Dewan Perwakilan Rakyat Daerah or DPRD) during this period, and the newlyformed district government could not, therefore, issue its own district regulations (Peraturan Daerah or Perda). Rather, until Malinau's DPRD was appointed in January 2001, the district government was legally bound to adhere to decrees issued by Bulungan's Bupati prior to partition and to Perda issued by Bulungan's DPRD. In this way, the activities of government decision-makers in Tanjung Selor have functioned, both formally and informally, as an important reference point for Malinau's kabupaten government.

Among the first tasks of Malinau's DPRD once it was installed was the selection of a new Bupati. In March 2001, the assembly elected Bp. Marthin Billa, who had theretofore served as District Secretary in Malinau's provisional government. Since taking his seat as Bupati in early-April,
Pak Marthin has moved quickly to present the DPRD with drafts of several Perdas that are likely to define significant aspects of the district's new regulatory regime. As of earlyMay 2001, the DPRD was reviewing six draft regulations on the following topics:

- Village Governance (Pemerintahan Desa);

- Formation, Dissolution, and Consolidation of Kelurahan (Pembentukan, Penghapusan, dan Penggabungan Kelurahan);

- Strengthening, Preservation, Protection, and Development of Adat Practices and Institutions (Pemberdayaan, Pelestarian, Perlindungan, dan Pengembangan Adat Istiadat dan Lembaga Adat);

- Issuance of Permits for the Extraction of Timber and Non-Timber Forest Products (Pemberian Ijin Pemungutan Hasil Hutan Kayu dan Hasil Hutan Bukan Kayu);

- Issuance of Permits for the Utilization of Timber (Pemberian Ijin Usaha Pemanfaatan Hasil Hutan Kayu);

- Retribution on Building Construction Permits (Retribusi Ijin Mendirikan Bangunan).

In addition to drafting these six Perdas, Malinau's new Bupati is taking steps to develop the district government's institutional capacity in strategic areas. In particular, Pak Marthin is seeking to establish a District Forestry Service (Dinas Kehutanan Daerah), which will undoubtedly play a critical administrative function in Malinau given that most of the district's land area remains under forest cover. In a conversation in May 2001, Pak Marthin emphasized the need for Malinau to have its own Forest Service, as the district 
government remains dependent on three CDK for even basic data:

We continue to rely on the CDK for information on HPH boundaries, log production, and company royalty payments. This information is critical to the Pemda [Malinau's district government]'s ability to administer the area under our jurisdiction. The CDK's sometimes don't want to share this information with us because they still report to the province. ${ }^{5}$

Pak Marthin reported that he envisions that Malinau's District Forestry Service would have a staff of about 30 to administer the 4.0 million ha of forestland located within the kabupaten's boundaries. Malinau's government is currently recruiting these staff from the Provincial Forest Service.

\subsection{DISTRICT REVENUE GENERATION}

During 2000, the first year of Malinau's formal existence as a kabupaten, the district had a budget of Rp 5.8 billion (or US $\$ 865,000$ at the January 2000 exchange rate of Rp 6,700 per US\$). As Table 5 shows, approximately 80 percent of this originated from petroleum sector revenues and 15 percent came from forest sector revenues. In both cases, these funds largely came to the district through allocations from the national government. Through year 2000, while Malinau's provisional district government was still in place, such allocations reached the kabupaten in a fairly circuitous manner: they were first allocated by the central government to East Kalimantan's provincial government, which then passed them on to kabupaten Bulungan, which in turn reallocated a portion to Malinau.

In September 2000 when interviews for this study was conducted, kabupaten officials in Malinau were still in the process of formulating the district's budget for 2001. While they were not prepared to release even preliminary budgetary targets, an official at Malinau's District Revenue Office (Dinas Pendapatan Daerah or Dispenda) indicated that the district government anticipated sharp reductions in fiscal allocations from the national government and was, therefore, under considerable pressure to secure revenues from local sources. ${ }^{6}$ At that point, the kabupaten's access to district-based revenues, or PAD (Pendapatan Asli Daerah) as they are known, were still very limited. Consistent with district regulations issued by kabupaten Bulungan before it was partitioned, Malinau's government had authority to collect six relatively minor forms of local tax:

- Group C mining tax (for sand, stones, etc)

- Surface and ground water tax

- Advertisement tax

- Hotel and restaurant tax

- Entertainment tax

- Street lighting tax

Table 5. Planned Year 2000 District Budget for Kabupaten Malinau (Anggaran Pendapatan Belanja Daerah (APBD), Rencana 2000 Dati II Malinau)

\begin{tabular}{lc}
\multicolumn{1}{c}{ Source } & Amount (Rp “000) \\
\hline Rural & 7,500 \\
Urban & 15,000 \\
Estate Crops & - \\
Forestry & 900,000 \\
Mining - Petroleum/Gas & $4,800,000$ \\
Mining - Non-Petroleum/Gas & 120,000 \\
Land Transfer Fees & 5,000 \\
Total & $\mathbf{5 , 8 7 5 , 5 0 0}$ \\
\hline
\end{tabular}

Source: Dispenda Kabupaten Malinau 
The Dispenda official acknowledged that the kabupaten government held little hope of significantly expanding its revenue base by raising these existing local taxes. $\mathrm{He}$ emphasized, rather, that under decentralisation Malinau would adopt a two-pronged strategy for raising PAD: On the one hand, the kabupaten government would take steps to secure a larger portion of the fees and royalties paid by companies operating within the district's boundaries, particularly HPH timber concessionholders. On the other hand, Malinau would seek to attract new capital investment in a variety of sectors.

\subsubsection{Securing an Increased Share of HPH Revenues}

Prior to the onset of the decentralization process, HPH concession-holders were formally required to pay eight specific fees to government agencies at various levels. ${ }^{7}$ These included the following:

1) Timber Concession Royalty (Iuran Hak Pengusahaan Hutan or IHPH): a one-time area-based fee paid at the time the HPH contract is initially issued.

2) Forest Resource Rent Provision (Provisi Sumber Daya Hutan or PSDH): a volumebased royalty on each cubic meter of timber harvested $\left(\mathrm{Rp} 58,000\right.$ per $\mathrm{m}^{3}$ of class A meranti in 2000).

3) Reforestation Fund (Dana Reboisasi or DR): a volume-based fee on each cubic meter of timber harvested, initially introduced as a bond to support reforestation activities (US\$ 16 per $^{3}$ of class A meranti in 2000).

4) Land and Building Tax (Pajak Bumi dan Bangunan or PBB): a flat-rate property tax based on an estimation of market capital value of land and buildings (approximately Rp 3,000 per ha in Malinau during 2000).

5) Ad Valorem Tax (Pajak Pertambahan Nilai or PPN): a tax of 10 percent of net earnings.

6) Income Tax (Pajak Penghasilan): a tax of 6 percent of net earnings.

7) Retribution for Motorized Transportation (Retribusi Kendaraan Bermotor): a fee based on number and size of vehicles using public roads.

8) Community Development Fee (Pembayaran Bina Desa): a volume-based fee paid to communities living in or near the concession site (US\$ 5 per $\mathrm{m}^{3}$ in 2000). Under the highly-centralized fiscal structures that were in place during the New Order period, HPH-holders paid the vast majority of these fees to the central government. In the case of the DR - the most lucrative of the timber-related fees, by far - the national government retained control over the full amount collected. However, in the case of the PSDH, the central government was required to redistribute 45 percent of the total amount collected to the provincial governments for use on development expenditures. Of the PSDH funds allocated to the provinces, one-third (or 15 percent of total PSDH receipts) were ear-marked for development expenditures at the kabupaten level. Indeed, much of the Rp 900,000,000 linked to forestry revenues in Malinau's 2000 budget originated from PSDH receipts.

Of the remaining tax categories, the central government was obliged to distribute substantial portions of the PBB, Ad Valorem Tax, and Income Tax to the provincial governments. It is likely that some portion of these were passed on to the kabupatens as part of their development grants from the provincial government. The Retribution for Motorized Transport is the only fee that the kabupaten governments were authorized to collect directly from HPH-holders. Most timber concessionaires have reportedly fulfilled their obligations related to the Community Development Fee by providing material assistance directly to communities living in and around their HPH sites. This is often done through allocations of seed or farming equipment or through the construction of schools or village facilities, with the $\mathrm{HPH}-$ holder submitting receipts to the government to document that the obligation has been met. ${ }^{8}$

Through the second half of 2000, East Kalimantan's provincial government engaged in protracted negotiations with the central 
government over fiscal balancing. At the heart of these negotiations was a dispute over what portion of East Kalimantan's natural resource revenues should flow to the national government. East Kalimantan officials argued that as a province rich in forest and mineral resources, the existing fiscal arrangements effectively meant that the bulk of the province's natural resource revenues flowed to Jakarta, which then used these to subsidize the budgets of resource-poor provinces. With regard to forestry revenues, East Kalimantan officials sought to secure an agreement that would require HPH-holders to pay 80 percent of their DR and 20 percent of the PSDH directly to the provincial government. ${ }^{9}$ In this way, the provincial government would retain a far larger portion of timber rents than in the past, as DR fees had previously been fully controlled by the central government and PSDH payments had gone first to Jakarta before a portion was redistributed among Indonesia's provinces.

While negotiations were going on between the national and provincial governments, the kabupaten governments in Malinau and several other timber-rich districts were also seeking to ensure that they would secure an adequate portion of the rents associated with $\log s$ harvested in their jurisdictions. In October 2000, the provincial news media carried reports that Bupati's in four districts and one municipality in northeast Kalimantan - Malinau, Bulungan, Nunukan, Berau, and Tarakan - threatened to break away from East Kalimantan if the provincial government did not guarantee that these kabupaten would receive fiscal allocations commensurate with the revenues flowing from them (Suara Kaltim 2000b). In particular, the Bupati's in these districts demanded that DR payments made by HPH-holders operating within their boundaries should be retained by the kabupaten government. Echoing the arguments made by the provincial government in its negotiations with Jakarta, the Bupati's argued that it was unfair for DR fees flowing from their districts to be used by East Kalimantan's provincial government to subsidize districts with less timber production.
In a conversation in early-May 2001, Malinau Bupati Marthin Billa downplayed these threats, emphasizing that they had only been made to steer the discourse related to fiscal balancing in a direction that would be more postive for timber-rich kabupaten. ${ }^{10}$

In addition to trying to secure a larger portion of existing fees and royalties for HPH-holders, there are indications that both the provincial and kabupaten governments may seek to expand their tax receipts by introducing new fees for timber concessionaires. Indeed, the Governor of East Kalimantan issued a decree (SK No 20/ 2000 ) in June 2000 requiring HPH-holders throughout the province to pay a 'compensation fee' to communities living in and around their concession sites. ${ }^{11}$ This fee was set at Rp 3,000 per $\mathrm{m}^{3}$ harvested during the period 1995-2000 and $\mathrm{Rp} \mathrm{5,000} \mathrm{per} \mathrm{m}^{3}$ for logs harvested from 2001 onward. $^{12}$ Decree No 20/2000 stipulates that HPH-holders are required to make these payments to the affected communities with the Camat (Subdistric Head), Kepala Desa (Village Head) and Kepala Adat (Customary Head) present as witnesses. However, according to one informant in Malinau, the kabupaten government lobbied hard to have this fee paid to the districts instead of directly to the communities involved, ostensibly so that it could ensure that the funds reach communities with legitimate claims to compensation from timber companies. ${ }^{13}$

In interviews conducted in September 2000, Malinau officials reported that they were seriously considering the possibility of introducing a volume-based royalty for $\operatorname{logs}$ harvested by HPH concession-holders. ${ }^{14}$ However, at that point they were reluctant to discuss either the potential size of this royalty or when it might be implemented. In an interview, the manager of one HPH reported that the district government had signaled that it might impose two new fees on timber concessionaires: a 'compensation fee' of Rp 20,000 per $^{3}$ for local communities and a fee of $\mathrm{Rp} 50,000$ per $\mathrm{m}^{3}$ for the kabupaten government. The unit manager at Inhutani II in 
Malinau indicated that the uncertainties associated with which levels of government hold the authority to impose new fees have created considerable difficulties for timber companies to run their businesses:

HPH-holders used to interact largely with the central government (pusat). Now we have to engage with the regional government (Pemda) but the regulations aren't clear. Pemda has been making lots of demands on us. Sometimes these come from the provincial government, but often they come from the kabupaten government as well. Pemda should not be making demands directly on the HPHs - they should make demands on the central government. Our company is fully prepared to pay whatever fees are required of us, but Pemda and the central government first need to agree on what the fees will be and to whom they are to be paid. ${ }^{15}$

\subsubsection{Generating New Investment}

In addition to seeking increased revenues from HPH-holders, Malinau's district government is also taking steps to attract new investment to the region. Priority sectors that have received attention thus far include: forestry; mining; plantations; agriculture; and tourism (Sekda Malinau 2001). In discussing the district's economic potential, Malinau officials generally emphasize the fact that the kabupaten encompasses a vast area that is rich in natural resources and yet has a relatively small population.

While much of the region's land area was allocated to HPH-holders during the New Order period, industrial timber extraction has thus far been limited by the rugged terrain that exists in many parts of the district. As a result, Malinau has some of East Kalimantan's last large tracts of primary forest. Malinau's mineral resources are, likewise, still largely unexplored, though industrial-scale coal mining operations is occuring near Long Loreh and community-run gold mining exists in parts of the Apo Kayan (Sekda Malinau 2001). Moreover, feasibility studies conducted before the 1997 financial crisis suggested that much of the lowland areas along the Malinau river basin would be conducive to plantation development, due to its flat terrain and relative accessibility. ${ }^{16}$ District planners view tourism as a potentially significant new revenue source, particularly if they can promote the unique cultural and ecological features of the Kayan-Mentarang National Park (Sekda Malinau 2001).

Malinau policymakers are keenly aware that the district's proximity to the East Malaysian states of Sabah and Sarawak offers strategic advantages in terms of access both to investors and to markets. Since Malinau's partition from Bulungan, a steady stream of Malaysian investors has come to the district in the hopes of arranging business deals with the new kabupaten government. Investors from Sabah have been particularly eager to secure access to the district's timber resources, as log supplies in that part of eastern Malaysia are heavily depleted. In August 2000, one Malinau-based timber broker described the situation as follows: 'The investors are on stand-by. They're just waiting for Pemda [the kabupaten government] to sort out the permit process [for timber harvesting]. ${ }^{17}$ This particular individual also noted that he had made several trips not only to Sabah but also to Sarawak and Singapore to seek out investors interested in financing logging operations in Malinau.

Investors from Malaysia and other countries have been drawn to Malinau, in part, because the ongoing processes of decentralisation and regional autonomy are likely to greatly expedite the procedures for obtaining investment approval. During the New Order period, foreign investors normally had to secure approval from the Capital Investment Coordinating Board (Badan Koordinasi Penanaman Modal or BKPM) and relevant Ministries in Jakarta, as well as from a variety of local and provincial government agencies. This process often consumed inordinate amounts of time, and frequently required substantial formal and informal payments. The Australian manager of an oil palm company operating just north of Malinau reported, for 
instance, that under the New Order regime's centralized approval process, his company had to obtain permits and/or letters of recommendation from the Ministry of Agriculture, Ministry of Forestry, the Governor of East Kalimantan, the Bupati of Bulungan, and Inhutani I before it could begin planting. ${ }^{18}$ This process took nearly two years and required informal payments amounting to approximately one-half of the US\$ 12 million that the company had invested through March 2000. ${ }^{19}$ This individual expressed a clear enthusiasm for the decentralisation process, speculating that 'it will cut out Jakarta and possibly Samarinda from the investment approval process. Investment and project operations will be much smoother and more efficient if companies can deal straight with the Bupati.'

To attract capital investment and facilitate the region's economic development, Malinau's government is actively seeking to improve the district's very limited physical infrastructure. The Bupati has indicated that his administration will make it a priority to build roads linking Malinau's five subdistricts; to improve port facilities near Kota Malinau ${ }^{20}$; and to expand air travel to some of the more remote parts of the district. Already, the district is close to completing a road from Bulungan's capital of Tanjung Selor to the town of Malinau, which was initiated before the onset of Indonesia's financial crisis in 1997 and largely funded by allocations from Jakarta. Kabupaten officials have indicated that this road will be extended in stages to eventually reach Long Bawan in Kayan-Mentarang area, which would open the district to expanded investment and trade with Sarawak. ${ }^{21}$ In May 2001, the Bupati reported that a more immediate priority would be to construct a road south from town of Malinau to link the Malinau basin with the upper Bahau region. Such a development would likely facilitate large-scale forest conversion for plantation development in this area.

District officials have indicated that with decentralisation underway, this and other infrastructural projects will now need to be funded largely by local sources. The kabupaten government is, therefore, seeking the assistance of HPH-holders, mining companies, and other potential investors in the region who would be capable of building roads and bridges. The head of Malinau's District Planning Agency (Badan Perencanaan Pembangunan Daerah or BAPPEDA) described the kabupaten's efforts as follows:

Until now, virtually all of the profits from HPH timber concessions have gone to support development in the center (pusat). And if you go to Jakarta, you see lots and lots of bridges. They even have bridges that go over bridges. But there aren't many rivers there. Here in Malinau, we have lots and lots of rivers, but very little money to build bridges. So now the district government is asking HPH-holders to offer some assistance for local development. ${ }^{22}$

Thus far, it appears that the district government has formulated its plans for road development without first carrying out either a comprehensive spatial planning process or serious assessments of these projects' likely environmental impacts.

\subsection{ALLOCATION OF IPPK FOREST CONVERSION PERMITS}

In April 2000, Malinau's district government began issuing small-scale forest conversion licenses known as Timber Extraction and Utilization Permits (Ijin Pemungutan dan Pemanfaatan Kayu or IPPK). The immediate legal basis for the allocation of IPPK permits in Malinau stems from Decision No 19/1999 signed by the Bupati of Bulungan, R.A. Bessing, on July 28, 1999 several months before kabupaten Bulungan was divided. ${ }^{23} 24$ Bupati Decision No 19/1999 stipulated that IPPK permits could be allocated to allow timber harvesting associated with forest conversion in areas designated as 'Social Forest' (Hutan Rakyat) or 'Privately-Owned Forest' (Hutan Milik). In assuming authority to issue conversion permits in these areas, the Bupati 
cited Government Regulation (Peraturan Pemerintah or PP) No 62/1998 regarding the delegation of partial authority in the forestry sector to the regions. ${ }^{25}$ Signed into law by President B.J. Habibie, PP 62/1998 stipulated that district governments would have authority to oversee activities related to the management of 'Privately-Owned Forest' and 'Social Forest', including 'tree planting, maintenance, harvesting, utilization, marketing, and development. ${ }^{26}$

According to the Bulungan Bupati's Decision No $19 / 1999$, IPPK permits can be assigned to individual land owners; village and government cooperatives; farmers' groups; community conservation groups; and companies or other agencies that are legally managing areas of 'Privately-Owned Forest'. Permit-holders are allowed to clear-fell forest in the areas defined in the IPPK contract 'as long as this does not have a negative effect.' Permit-holders are not required to pay PSDH or other national and provincial-level royalties associated with the HPH concession system, though they are subject to fees imposed by the kabupaten government. The IPPK permit may range in duration between 3 and 6 months, and if stands of commercial timber remain by the time the license expires, it may be renewed up to three times.

With the IPPK regulations on the books, the kabupaten government in Bulungan moved aggressively to generate new revenues for the district budget. Between August 1999 and August 2000, Bulungan's Bupati and District Secretary issued some 75 IPPK permits covering just under 10,000 ha (Bagian Perekonomian 2000). ${ }^{27}$ Following the district's partition in late-1999, the Bupati in Malinau began issuing IPPKs in April 2000. Through February 2001, Malinau's district government issued at least 39 IPPKs covering an aggregate area of 56,000 ha (see Table 6). These permits cover areas ranging in size from 100 ha to 3,000 ha, and are located in two of the district's five kecamatan: Malinau and Mentarang. ${ }^{28}$ In each case, the IPPK-holder has been given the right to clear the designated area of standing timber in order to convert the land to agricultural use or plantations. Whereas the Bulungan Bupati's Decision No 19/1999 stipulates that IPPK permits should be valid for periods of 3-6 months, the permits issued by the Bupati of Malinau often state that the IPPK-holder must only initiate activities at the cutting site within six months from the date that the permit was issued. Companies receiving IPPKs in Malinau reported that their permits are valid for periods ranging from six to twelve months, though it is often unclear if these time limits have been formally imposed by the district government.

Malinau's kabupaten government has sought to generate formal revenues from the allocation of small-scale forest conversion permits through the introduction of two new fees. First, IPPK-holders are required to pay a one-time 'third party donation' (sumbangan pihak ketiga) of Rp 200,000 per ha. ${ }^{29}$ Second, recipients of IPPK permits are required to pay a 'production retribution' (retribusi produksi) of Rp 15,000 per $\mathrm{m}^{3}$ of timber harvested. With these two fees, it can be projected that the kabupaten government should be able to collect approximately $\mathrm{Rp} 53$ billion in revenues for the district budget from the 39 IPPKs issued through February 2001 (or US\$ 5.3 million at an exchange rate of Rp 10,000/ US\$). This amounts to roughly nine times kabupaten Malinau's planned budget for 2000.

\subsubsection{New Pressures on Forests}

There are clear indications that the allocation of IPPK permits by the kabupaten government in Malinau is placing significant new pressures on that district's forests. Until recently, commercial timber extraction in the Malinau area was organized, at least formally, around HPH timber concessions, which require logging companies to practice selective felling, rotational harvesting, and enrichment planting. While many $\mathrm{HPH}-$ holders and their contractors are believed to have regularly overharvested their cutting blocs and to have carried out only minimal replanting, their concession sites have generally left large areas of secondary forest standing. Although often quite degraded, these secondary forests have played a 
Table 6. List of IPPK Permits Issued by Malinau District Government, April 2000-February 2001

\begin{tabular}{|c|c|c|c|c|c|}
\hline IPPK Holder & SK No. & Date & Location & Area(ha) & Volume $\left(\mathrm{m}^{3}\right)$ \\
\hline CV Putra Mentarang Kaltim & $17 / 2000$ & April 17, 2000 & $\begin{array}{l}\text { Desa Long Pala } \\
\text { Kec. Mentarang }\end{array}$ & 100 & 5,019 \\
\hline CV Putra Mentarang Kaltim & $20 / 2000$ & April 20, 2000 & Desa Luba/ & 500 & 25,694 \\
\hline CV Putra Mentarang Kaltim & $21 / 2000$ & April 24, 2000 & $\begin{array}{l}\text { Selidung Kec. Malin } \\
\text { Desa Kabiran/ } \\
\text { Tg Sepatui Kec. Mal }\end{array}$ & $\begin{array}{l}\text { au } \\
600 \\
\text { alinau }\end{array}$ & 38,644 \\
\hline CV Putra Mentarang Kaltim & $27 / 2000$ & May 4, 2000 & $\begin{array}{l}\text { Desa Long Loreh } \\
\text { Kec. Malinau }\end{array}$ & 1,050 & 44,404 \\
\hline CV Wana Bakti & $38 / 2000$ & May 29, 2000 & $\begin{array}{l}\text { Desa Sesua } \\
\text { Kec. Malinau }\end{array}$ & 500 & 25,244 \\
\hline $\begin{array}{l}\text { Pemegang Kuasa Tanah } \\
\text { Adat Long Sulit }\end{array}$ & $50 / 2000$ & June 21, 2000 & $\begin{array}{l}\text { Desa Long Sulit } \\
\text { Kec. Mentarang }\end{array}$ & 700 & 37,839 \\
\hline CV Putra Mentarang Kaltim & $80 / 2000$ & June 21, 2000 & $\begin{array}{l}\text { Desa Paking } \\
\text { Kec. Malinau }\end{array}$ & 2,600 & 130,344 \\
\hline CV Wana Bakti & $51 / 2000$ & June 23, 2000 & $\begin{array}{l}\text { Ds. Long Adiu/ } \\
\text { Punan Adiu Kec. Ma }\end{array}$ & $\begin{array}{r}1,500 \\
\text { alinau }\end{array}$ & 75,773 \\
\hline CV Wana Bakti & $81 / 2000$ & July 21, 2000 & $\begin{array}{l}\text { Desa Batu Lidung } \\
\text { Kec. Mentarang }\end{array}$ & 1,500 & 74,150 \\
\hline CV Lestari Timur Indonesia & $68 / 2000$ & July 5,2000 & $\begin{array}{l}\text { Desa Paking } \\
\text { Kec. Mentarang }\end{array}$ & 1,000 & 49,493 \\
\hline Koperasi Berdikari & $69 / 2000$ & July 7,2000 & $\begin{array}{l}\text { Sungai Segudang } \\
\text { Kec. Malinau }\end{array}$ & 1,000 & 40,935 \\
\hline Koperasi Kehutanan & $66 / 2000$ & July 13, 2000 & $\begin{array}{l}\text { S. Gita Bengalun } \\
\text { Kec. Malinau }\end{array}$ & 1,000 & 50,005 \\
\hline CV Hanura & $72 / 20000$ & July 7,2000 & $\begin{array}{l}\text { Desa Langap } \\
\text { Kec. Malinau }\end{array}$ & 3,000 & 147,889 \\
\hline Koperasi Galik Hasa Bulet & $76 / 2000$ & July 24, 2000 & $\begin{array}{l}\text { Batang Indai/Gong } \\
\text { Solok Kec. Malinau }\end{array}$ & 1,500 & 73,967 \\
\hline CV Putra Mentarang Kaltim & $77 / 2000$ & July 7,2000 & $\begin{array}{l}\text { S. Gong Solok } \\
\text { Kec. Malinau }\end{array}$ & 1,600 & 94,773 \\
\hline CV Putra Mentarang Kaltim & $78 / 2000$ & July 7,2000 & $\begin{array}{l}\text { Desa Seruyung } \\
\text { Kec. Malinau }\end{array}$ & 600 & 31,401 \\
\hline CV Putra Mentarang Kaltim & $79 / 2000$ & July 7,2000 & $\begin{array}{l}\text { Desa Salap } \\
\text { Kec. Malinau }\end{array}$ & 600 & 30,687 \\
\hline CV Putra Mentarang Kaltim & $80 / 2000$ & July 21, 2000 & $\begin{array}{l}\text { Desa Paking } \\
\text { Kec. Mentarang }\end{array}$ & 2,600 & $130,000^{*}$ \\
\hline CV Wana Bakti & $81 / 2000$ & July 21, 2000 & $\begin{array}{l}\text { Desa Batu Lidung } \\
\text { Kec. Malinau }\end{array}$ & n.a. & n.a. \\
\hline CV Gading Indah & $83 / 2000$ & August 10, 2000 & $\begin{array}{l}\text { Setarap/Punan } \\
\text { Setarap Kec. Malina }\end{array}$ & $\begin{array}{l}1,200 \\
a u\end{array}$ & $60,000^{*}$ \\
\hline $\begin{array}{l}\text { Pemegang Kuasa } \\
\text { Tanah Adat Long Sulit }\end{array}$ & $92 / 2000$ & September 4, 2000 & $\begin{array}{l}\text { Desa Long Sulit } \\
\text { Kec. Malinau }\end{array}$ & 1,300 & $65,000^{*}$ \\
\hline CV Kelawing Jaya & $129 / 2000$ & November 1, 2000 & $\begin{array}{l}\text { Desa Adiu/Punan } \\
\text { Adiu Kec. Malinau }\end{array}$ & 1,500 & $75,000^{*}$ \\
\hline Koperasi Tumu Bagu & $130 / 2000$ & November 2, 2000 & $\begin{array}{l}\text { S. Pandan, } \\
\text { Gong Solok Kec. Ma }\end{array}$ & $\begin{array}{l}2,000 \\
\text { lalinau }\end{array}$ & $100,000^{*}$ \\
\hline Koperasi Tumu Bagu & $131 / 2000$ & November 11, 2000 & $\begin{array}{l}\text { S. Gulama, Gong } \\
\text { Solok Kec. Malinau }\end{array}$ & 1,500 & $75,000^{*}$ \\
\hline CV Sinar Busakan & $133 / 2000$ & November 17, 2000 & $\begin{array}{l}\text { Desa Long Simau } \\
\text { Kec. Mentarang }\end{array}$ & 2,000 & $100,000^{*}$ \\
\hline CV Putra Surip Wijaya & $140 / 2000$ & November 17, 2000 & $\begin{array}{l}\text { Desa Nunuk Tanah } \\
\text { Kibang Kec. Malinau }\end{array}$ & 2,000 & $100,000^{*}$ \\
\hline CV Putra Surip Wijaya & $142 / 2000$ & November 17, 2000 & $\begin{array}{l}\text { Desa Sengayan } \\
\text { Kec. Malinau }\end{array}$ & 2,000 & $100,000^{*}$ \\
\hline PT Lestari Timur Indonusa & $145 / 2000$ & November 21, 2000 & $\begin{array}{l}\text { Desa Paking } \\
\text { Kec. Mentarang }\end{array}$ & n.a. & n.a. \\
\hline PT Bakti Bumi Perdana & $153 / 2000$ & December 12, 2000 & $\begin{array}{l}\text { Desa Kelapis } \\
\text { Kec. Malinau }\end{array}$ & 1,000 & $50,000^{*}$ \\
\hline PT Bakti Bumi Perdana & $154 / 2000$ & December 13, 2000 & $\begin{array}{l}\text { Desa Selidung } \\
\text { Kec. Malinau }\end{array}$ & 1,000 & $50,000^{*}$ \\
\hline
\end{tabular}


Table 6. Continued

\begin{tabular}{|c|c|c|c|c|c|}
\hline IPPK Holder & SK No. & Date & Location & Area(ha) & Volume $\left(\mathrm{m}^{3}\right)$ \\
\hline Koperasi Serba Usaha Meranti & $6 / 2001$ & January ?, 2001 & $\begin{array}{l}\text { Desa Tg Nanga } \\
\text { Kec. Malinau }\end{array}$ & 2,000 & $100,000^{*}$ \\
\hline PT Bakti Bumi Perdana & 9/2001 & January 30, 2001 & $\begin{array}{l}\text { Desa Putat } \\
\text { Kec. Malinau }\end{array}$ & 1,000 & $50,000^{*}$ \\
\hline PT Bakti Bumi Perdana & $10 / 2001$ & January 30, 2001 & $\begin{array}{l}\text { Desa Selidung } \\
\text { Kec. Malinau }\end{array}$ & 1,000 & $50,000^{*}$ \\
\hline PT Bakti Bumi Perdana & $11 / 2001$ & January 30, 2001 & $\begin{array}{l}\text { Desa Selidung } \\
\text { Kec. Malinau }\end{array}$ & 1,000 & $50,000^{*}$ \\
\hline PT Bakti Bumi Perdana & $12 / 2001$ & January 30, 2001 & $\begin{array}{l}\text { Desa Luba } \\
\text { Kec. Malinau }\end{array}$ & 1,000 & $50,000^{*}$ \\
\hline PT Malinau Jaya Sakti & $21 / 2001$ & February 12, 2001 & $\begin{array}{l}\text { Desa Sesua/Punan } \\
\text { Bengalun Kec. Malinau }\end{array}$ & 3,000 & $150,000^{*}$ \\
\hline CV Putra Harapan & $26 / 2001$ & February 16, 2001 & $\begin{array}{l}\text { Sungai Gita } \\
\text { Bengalun Kec. Malinau }\end{array}$ & 5,000 & $250,000^{*}$ \\
\hline $\begin{array}{l}\text { Pemegang Kuasa Tanah Adat } \\
\text { Desa Long Sulit }\end{array}$ & $30 / 2001$ & February 20, 2001 & $\begin{array}{l}\text { Desa Long Sulit } \\
\text { Kec. Malinau }\end{array}$ & 3,000 & $150,000^{*}$ \\
\hline CV Wana Bakti & $32 / 2001$ & February 21, 2001 & $\begin{array}{l}\text { Desa Sesua } \\
\text { Kec. Malinau }\end{array}$ & 1,500 & $75,000^{*}$ \\
\hline Total (39 IPPKs) & & & & 55,950 & $2,806,261$ \\
\hline
\end{tabular}

Source: Pemerintah Daerah Kabupaten Malinau.(2000; 2001). *Volume figures with asterisk are estimates based on the assumption that each hectare yields $50 \mathrm{~m}^{3}$ of merchantable timber. Otherwise, estimated volumes are those recorded in the IPPK contract.

vital role in maintaining forest cover and in sustaining the subsistence livelihoods of forestdependent communities.

With the emergence of the IPPK system, formal timber extraction in Malinau and other parts of East Kalimantan is becoming increasingly organized around forest conversion. The IPPK permits allow the clear-felling of designated forested areas, ostensibly so that these sites can then be used for agricultural purposes. Averaging just under 1,500 ha each, the exploitable areas delineated by the 39 IPPK permits issued in Malinau through February 2001 would, at first glance, seem to be relatively small - particularly when compared to the size of HPH timber concessions in the region. The areas assigned to IPPK-holders take on considerably greater significance, however, when it is considered that the permits are valid for periods of six to twelve months. This effectively means that the 56,000 ha thus far allocated to IPPK-holders through February 2001 represents the aggregate area that district officials have scheduled for conversion by early 2002 .

Moreover, according to one local timber broker who has been involved in arranging several IPPK permits, 'the kabupaten government has indicated that investors will be able to obtain new conversion permits once their initial IPPKs expire. ${ }^{30}$ Indeed, one IPPK-holder reported that he had secured the right to exploit an area that covered 25,000 ha, but that he would do so in stages, using IPPK permits for 1,000 ha at a time. ${ }^{31}$ To the extent that Malinau officials do make similarly large areas of forest available for clearing in future years, the loss of forest cover associated with IPPK conversion will ultimately be quite substantial. Moreover, the negative social and environmental effects associated with large-scale forest conversion are likely to be exacerbated if the district government continues to allocate IPPK permits before a comprehensive and participatory spatial planning process has been carried out. 
It is also significant that the Malinau district government has issued the IPPK permits well before an effective forestry regulatory agency has been established at the kabupaten-level. In this regard, there is little evidence that the district government has either the political will or the institutional capacity to effectively monitor the activities of IPPK-holders once they have initiated their operations. ${ }^{32}$ A forestry official from CDK Bulungan Tengah who is posted in Malinau agreed that Dinas Kehutanan's capacity to regulate IPPK-holders is still quite limited, noting that 'the rules are altogether unclear.' 33 Moreover, among timber industry actors interviewed in Malinau, Bulungan, and Tarakan, there is a widely-held sense that the IPPK system has been structured, in part, to legitimize the region's theretofore informal timber economy. According to one timber company officer, 'there is no agency to regulate the IPPKs. The area to be cut by the CV [IPPK-holder] depends on the company's arrangement with the local communities (masyarakat). ${ }^{34}$

Some industry sources claim that the IPPKholders have already brought much larger numbers of heavy equipment into the region than they would need to log the areas that have been formally allocated to them. In September 2000, for instance, Inhutani I officials in Tarakan reported that the IPPK-holders had brought over 370 pieces of new heavy equipment into Bulungan, Malinau, and Nunukan districts over the preceding year. ${ }^{35}$ At that time, they described the situation as follows:

A year ago, there were probably 200 pieces of heavy equipment in the region. These were all formally registered, so that petrol could be allocated... ${ }^{36}$ The flood of equipment coming in now from Malaysia is mostly unregistered and of questionable legal status... Now [the head of the region's main illegal logging syndicate] is planning to bring in 400 more pieces of heavy equipment. ${ }^{37}$

The Inhutani officials attributed this influx of bulldozers, logging trucks, log loaders, and graders to decentralisation both in the forestry sector and in the government's procedures for regulating imports:

In the past, timber companies seeking to import heavy equipment were required to obtain permits from the Ministry of Forestry (with prior recommendations from both Kanwil and Dinas Kehutanan) and the Ministry of Industry and Trade in Jakarta. Now, the CVs [i.e. the IPPK permit-holders] are not going through the Departments [to get import permits]. They are just going through the Bupati's and the [regional] Customs Office in Tarakan. ${ }^{38}$

A Tarakan-based Customs official confirmed that his office had, indeed, approved import permits for a significantly larger number of pieces of heavy equipment in 2000 than it had in previous years. He indicated that these permits did not require prior approval from the Ministry of Industry and Trade in Jakarta because they were for 'used equipment' (barang bukan baru) that was being 'imported temporarily' (impor sementara). ${ }^{39}$ He claimed that the national government still regulates imports of goods that either are new or that are classified as 'definitive imports' (impor definitif) - that is, which will not later be 're-exported.' Inhutani officials, however, vigorously questioned whether the regulations governing 'temporary imports' were being applied systematically, arguing instead that Malaysian investors were exploiting the loose regulatory environment to move their equipment across the border from Sabah.

These reports may indeed signal that the new investors expect either to be granted much larger areas of forest than those assigned to IPPKholders thus far, or to gain informal access to areas outside of those delineated in their IPPK permits. In either case, the IPPK system of timber extraction is likely to place considerably greater pressures on Malinau's forests than district policymakers have yet acknowledged. 


\subsubsection{Timber Profits for New Actors}

In addition to generating revenues for Malinau's district budget, the allocation of IPPK permits by the kabupaten government has created profitmaking opportunities for a range of actors who had theretofore been largely excluded from Indonesia's formal timber sector. To date, most of the logging companies to receive IPPK licenses in Malinau are joint ventures between local entrepreneurs - or putera daerah (literally, 'children of the region' or 'local sons'), as they are known in Malinau - and either regionally-based Indonesian or Malaysian Chinese timber buyers.

In such partnerships, the role of the local entrepreneurs is typically two-fold: On the one hand, they play a critical function in identifying accessible forest areas that are well-stocked with commercial timber species and in brokering harvesting agreements with nearby communities that may have tenure claims to these areas. ${ }^{40} \mathrm{On}$ the other hand, the putera daerah are generally responsible for arranging the IPPK permit and all supporting documentation with the kabupaten government. These individuals invariably have strong political connections among the officials in charge of Malinau's government offices, which in some cases, are reinforced by family ties and/ or shared ethnic bonds. ${ }^{41}$

For their contribution, the local entrepreneurs often receive a 30-40 percent share in the ventures associated with each IPPK they arrange. ${ }^{42}$ The remaining shares are held by the investor (or inspektur, as many in Malinau call them), who provide much of the financing and equipment needed to $\log$ the areas specified in the IPPK permit. When interviewed for this study, most local entrepreneurs were reluctant to identify the specific investors who are backing their activities. However, it was widely acknowledged that much of the recent investment in Malinau's burgeoning timber industry has come from Malaysian Chinese timber buyers, who are seeking to secure new supplies of $\operatorname{logs}$ for wood processing industries in Sabah. In the case of one company that has received multiple IPPK permits, the primary investor is an Indonesian Chinese businessman who apparently has roots in the
Malinau region, but who has been based in Balikpapan for the past decade.

Many of the investors now active in the Malinau region are reported to be closely tied to illegal logging syndicates that operate out of Tanjung Selor in Bulungan and Tarakan to smuggle logs across the border to Sabah. As noted above, there is speculation that these syndicates may, in fact, seek to use the IPPK permits allocated by the kabupaten government to expand their operations under the guise of legality. For logging companies that had previously been engaged in illegal timber harvesting, securing an IPPK permit offers two important advantages: First, it provides a semilegal cover for continued informal logging activities in areas near those specified in the IPPK conversion license. Second, it provides these companies with an apparently legitimate reason to bring large numbers of heavy equipment into the region. Without the IPPK permit, it would be difficult for small-scale timber companies to justify - either to government regulatory agencies or to local communities - the need to land heavy equipment at their logging sites.

At least at the discursive level, forestdependent communities represent a third set of actors who stand to benefit from the allocation of IPPK licenses. Indeed, the kabupaten government requires that logging companies applying for an IPPK permit must, first, secure a harvesting agreement with communities living in or around the forested area which will be logged. In interviews, district officials emphasized that this requirement is designed to ensure that the new logging permits issued by the kabupaten government will generate tangible benefits for the people (masyarakat) of Malinau in a manner that the HPH system has failed to do. The District Secretary, among others, explained that the HPH system categorically marginalized local peoples, as concession maps were routinely drawn up in Jakarta without concern for the land and forest tenure rights of adat communities. ${ }^{43}$ In addition, he noted that the local development expenditures that HPH-holders were obliged to make often went unpaid and rarely amounted 
to much, when compared to the profits the timber companies took out of the region. (The specific cash and non-cash benefits that IPPKholders have agreed to provide to communities are examined in detail later in this paper).

In addition to the formal profits flowing to the brokers, investors, and local communities, the allocation of IPPK permits has also apparently created lucrative opportunities for informal profit flows to government officials involved in the permit process. Several informants interviewed during the course of this study indicated that informal payments were routinely required at each step of the permit approval process where a signature is needed. Timber brokers interviewed in September 2000 indicated that they had paid as much as Rp 50 million (or roughly US\$7,500 at an exchange rate of Rp 6,700/US\$) for individual signatures needed to secure the IPPK permit. ${ }^{44}$ They noted, however, that the investors will generally recoup such fees by withholding an equivalent amount from their payments to the local communities whose forests they are logging.

\subsection{OVERLAP OF IPPK CONVERSION AREAS AND HPH TIMBER CONCESSIONS}

With the issuance of PP No 6/1999, the central government gave authority to district governments to allocate 'Forest Product Harvest Concession' (Hak Pemungutan Hasil Hutan or HPHH) in areas classified as 'Forest Estate'. The implementing regulations related to HPHHs were detailed in a series of decrees from the Ministry of Forestry and Estate Crops in May 1999. Specifically, Ministerial Decision No 310/1999 stipulated that district governments could issue HPHHs up to 100 ha in size for the extraction of timber within areas classified as 'Conversion Forest' or areas of Production Forest "that was going to be converted or reclassified." 45 Decision No 310/ 1999, moreover, stated that HPHHs for the extraction of timber could not be issued for areas that were already encumbered with a HPH timber concession license or an IPK (Ijin Pemanfaatan Kayu) timber clearance permit. However, a subsequent decree, Ministerial Decision No 317/1999, outlined a process through which adat communities can obtain HPHHs to extract both timber and nontimber forest products from 'Production Forest' areas that have already been assigned to $\mathrm{HPH}$ concessionaires. ${ }^{46}$

While many kabupaten governments in East Kalimantan and elsewhere responded to these new regulations by allocating large numbers of HPHHs, neither the Bupati in Bulungan nor his counterpart in Malinau have done so. On the contrary, the small-scale timber extraction permits allocated by the Bupati's of Bulungan and Malinau have been limited to IPPKs, which are legally restricted to areas designated as Hutan Rakyat (Community Forest) or Hutan Milik (Privately-Owned Forest) - that is, to areas that fall outside of the Permanent Forest Estate (Kawasan Budidaya Kehutanan). In practice, however, the kabupaten governments in Malinau and Bulungan have allocated numerous IPPK permits in areas that fall within the boundaries of active HPH timber concessions.

In both districts, concession areas managed by the state-owned forestry enterprises, Inhutani I and II, have been particularly susceptible to the allocation of overlapping IPPK permits. In Malinau, for instance, the kabupaten government has issued at least two IPPKs in areas that overlap directly with portions of Inhutani II's 48,300 ha concession. One of these was issued to CV Hanura, and one to CV Sebuku Lestari (see Map 2). The area assigned to Sebuku Lestari under the IPPK permit extends across the northern boundary of Inhutani II's HPH area into a neighboring concession held by Inhutani I. The area assigned to CV Hanura is divided into two locations, leading to the misinterpretation by some that the company manages two IPPK's in the concession. 
Map 2. Location of IPPKs at PT INHUTANI II Malinau, East Kalimantan

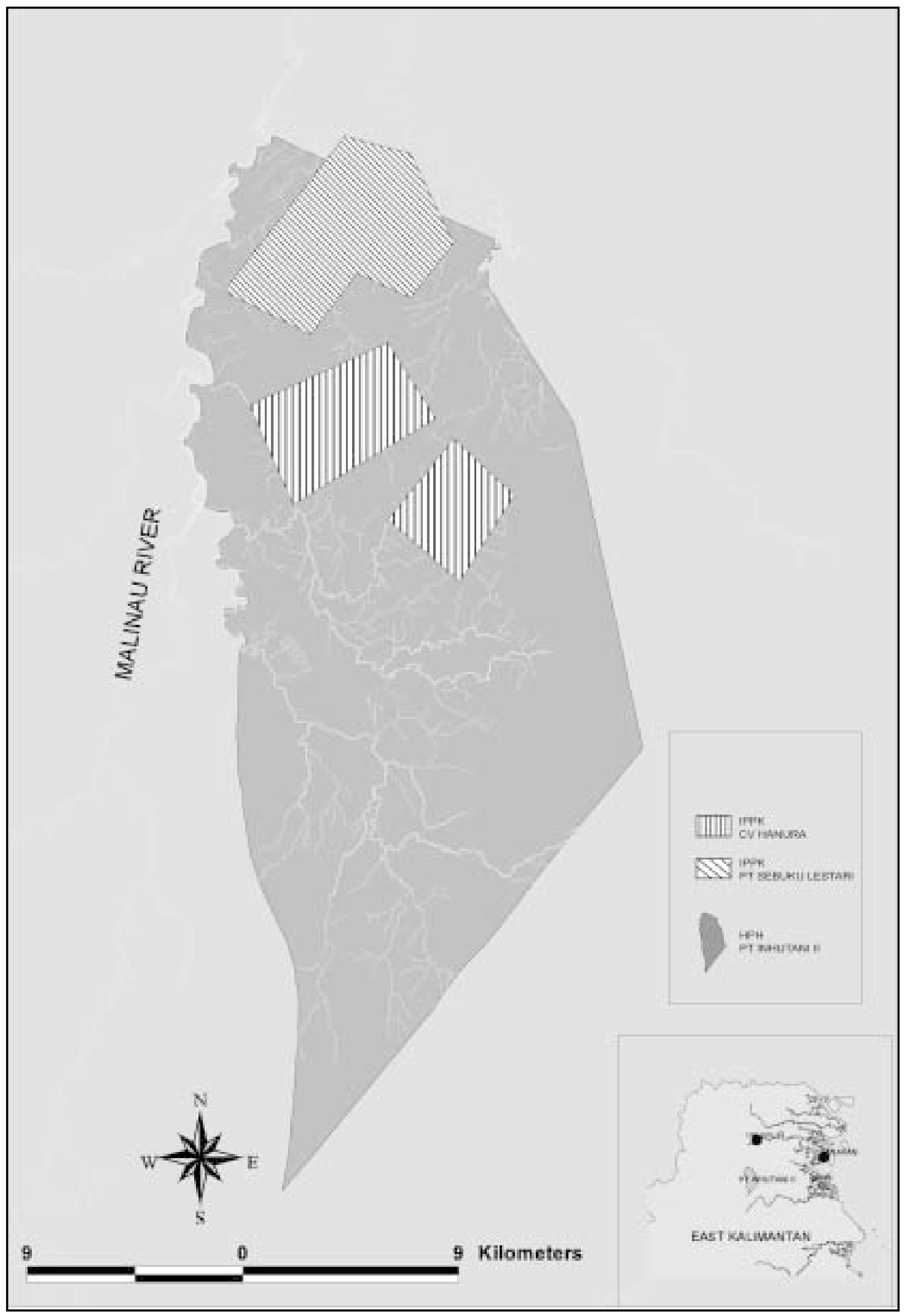


In interviews, several industry actors and government officials speculated that the Bupati's in both kabupaten have been targeting concessions held by the Inhutani's in order to challenge the national government's ability to control timber exploitation in their districts. An official in Malinau's district auditing agency, for instance, argued that the kabupaten governments have been acting strategically to expand the district's role in the timber sector beyond simply receiving a larger share of formal logging revenues:

The national and provincial governments are struggling with each other over how to redistribute the HPH royalties. They think that the kabupatens will accept whatever portion the Center and the Province decide to give them. But actually, the kabupatens are implementing regional autonomy in a purer form ('dalam bentuk yang lebih murni'). Just like in $\mathrm{Kutai}^{47}$, the Bupati's in Malinau and Bulungan are showing that they can control forests being managed by HPH-holders. They're not just looking for a share of the HPH revenues - they want to decide who gets the permits, who gets to operate there. ${ }^{48}$

Another informant suggested that the Bupati's have been allocating IPPKs in areas theretofore managed by the Inhutani's in order to send a political message to other HPH-holders operating within their districts. ${ }^{49}$ Specifically, he argued, the Bupati's have sought to make it clear to large-scale concessionaires that their continued access to timber profits is now dependent upon the support of the kabupaten government and cannot be guaranteed, as in the past, by political backing from Jakarta. The informant implied that this show-of-force on the part of the Bupati's was necessary to ensure that HPH-holders are responsive both to the district government's new regulations and to periodic requests on the part of local officials for informal payments.

Officials at both Inhutani I and II claimed that whatever their motivations, the Bupati's have, in fact, transgressed the limits of their legal authority in allocating IPPKs within the boundaries of existing concession-holders. The Director of Inhutani I's Tarakan Unit, for instance, emphasized that there is no legal statute to support the issuance of IPPK permits in areas classified as 'Permanent Forest Estate'; rather, the only permissible forest conversion permits in such areas are IPKs, which may be issued by the Ministry of Forestry. The manager of Inhutani II's Malinau Unit, likewise, questioned how the Bupati could have the right to allocate an IPPK conversion permit within an existing timber concession, when that company's HPH license had not first been revoked. Furthermore, staff at both Inhutani's noted that the district governments have shown little inclination or capacity to ensure that recipients of IPPK permits operate only within whatever areas have been assigned to them. According to an Inhutani I camp manager,

There is no regulatory agency to oversee the activities of IPPK-holders. The area to be cut by the CV [logging company] depends on its arrangement with the local communities (masyarakat)... The IPPKs don't seem to have any clear boundaries. Many of the contracts don't even have real maps attached to them. ${ }^{50}$

Individuals involved with the companies that have received IPPK permits overlapping with $\mathrm{HPH}$ areas offered a strikingly different perspective. The proprietor of CV Hanura, for instance, argued in an interview that the term 'overlap' ('tumpang tindih') in this context has little meaning:

The local communities (masyarakat) have already rejected Inhutani, so Inhutani no longer has any rights. CV Hanura has obtained authority from the communities to $\log$ in the 'ex-Inhutani' area.... Inhutani has done nothing for the communities for the last 32 years, so they have no basis to make a claim to this area. ${ }^{51}$ 
A local timber broker who works closely with CV Putra Mentarang described the situation in very similar terms, claiming that local communities had seized back large areas from Inhutani:

After 35 years, what has Inhutani given to the communities? It used to be that Inhutani would chase off the communities. Now, it is the communities that are chasing Inhutani. If Inhutani tries to operate their logging equipment in these areas, the communities will stop them. In Semendurut and Sembuak [two areas where IPPKs have begun operating within Inhutani concession boundaries], Inhutani has thrown up its hands. The IPPKs are operating in areas that have been 'released' ('areal lepas'). ${ }^{52}$

When interviewed in September 2000, thenDistrict Secretary (and now Bupati) Marthin Billa denied that the kabupaten government was targeting concession areas controlled by the Inhutani's or other concession-holders. Both he and members of his staff attributed the allocation of IPPKs in areas that overlap with Inhutani HPH boundaries to technical errors on the part of the branch office of the Provincial Forestry Service (Cabang Dinas Kehutanan, or CDK). They pointed out that the IPPK permit application process required the Bupati to obtain a 'Letter of Technical Advice' from the CDK indicating that the area in question does not fall within the Permanent Forest Estate. ${ }^{53}$ The District Secretary claimed that the Bupati's office has, until now, been illequipped to evaluate applications for IPPK permits, as it has not had access to HPH maps and other basic data related to timber production in Malinau. He noted that the kabupaten government had requested maps, log production data, and other relevant information from the Provincial Forestry Service, but CDK had not yet complied with this request.

Another district official pointed out that the various $\mathrm{CDK}$ offices, in fact, have a distinct interest in maintaining tight control over forestry data, as that is ultimately what allows CDK to maintain a critical role in the timber licensing and revenue collection processes. ${ }^{54} \mathrm{He}$ further noted that CDK officials have often exploited their role in these processes to generate lucrative informal profits.

\subsubsection{Response by Inhutani's and other HPH-holders}

Officers interviewed at both Inhutani I and II indicated that they received no advance warning that IPPK permits would be issued for areas that fell within those companies' HPH boundaries. Rather, they first found out about the IPPKs when the new permit holders appeared in the Inhutani concession sites and began organizing their own logging operations. In most cases, the Inhutani officials reported, they initially had no clear information about the identity of the companies that had obtained the IPPK permits or what other actors were involved in backing their activities. In each instance, the Inhutani's filed grievances with the Bupati's office. However, officials of both companies interviewed in September 2000 claimed that the Bupati had thus far offered no clear steps for resolving the issue of overlapping timber harvesting permits. As one Inhutani officer put it, 'The Bupati simply said that it would be up to the communities to decide which company they want to work with. ${ }^{55}$

In the weeks following the initial round of IPPK allocations by the Bupati of Bulungan in late-1999, the Inhutani's began lobbying for intervention on the part of both the national and provincial governments. In Jakarta, these efforts resulted in the Director General of Production Forestry, Ir. Waskito Suryodibroto, sending a letter to East Kalimantan's Governor Suwarna, requesting his assistance in suspending the issuance of additional IPPK permits in Bulungan. ${ }^{56}$ Dated September 30, 1999, Pak Waskito's letter explained that the implementing regulations for the central government's transfer of forest administration responsibilities to the regions (daerah) had not yet been finalized. Within this context, Pak Waskito claimed, it was imperative to 'avoid the possibility of overlapping timber extraction permits that could confuse the populace ('membingungkan 
masyarakat').' Governor Suwarna responded by issuing a letter on November 10 to the Bupati of Bulungan, ordering that the implementation of the Bupati's Decision No 19/1999 regarding the allocation of IPPK permits be suspended. ${ }^{57}$ Inhutani officials interviewed for this study pointed out that the Governor's order would have automatically applied to the Bupati of Malinau, as well, being that the new kabupaten was still subject to regulations issued in Bulungan before its partition.

The Governor's order had little practical effect on the allocation of IPPKs in Bulungan or Malinau. Through early-2000, the Bupati of Bulungan issued dozens of new IPPKs, while the Bupati of Malinau only began issuing IPPKs in April of that year. Similar processes played out in most other districts of East Kalimantan during this period, as Bupati's allocated large numbers of IPPKs and HPHHs. In response to intensive lobbying efforts by the Inhutani's and the Indonesian Forest Concession Holders' Association (Asosiasi Pengusaha Hutan Indonesia or APHI), the Ministry of Forestry and Estate Crops issued a decree on April 13, 2000 revoking Ministerial Decision No 310/ 1999, which gave kabupaten governments authority to issue HPHHs. On May 22, Minister Nur Mahmudi Ismail also sent a letter to all of Indonesia's Governors and Bupati's calling for a complete halt on conversion of areas within the 'Forest Estate' (Kawasan Hutan). ${ }^{58}$ Specifically, he called on the Governors and Bupati's to stop allocating conversion permits and to push companies that have obtained conversion permits for areas that have already been released from the Forest Estate to plant these areas immediately. In this letter, the Minister noted that the Government of Indonesia had made a commitment to the International Monetary Fund (IMF) to stop forest conversion, implying that the country's financial recovery could be jeopardized by the allocation of new IPPK permits.

During mid-2000, APHI's East Kalimantan Regional Branch, of which Inhutani I and II are active members, focused its lobbying efforts on the provincial government. At each of its monthly meetings, the Concessionaires' Association raised the HPHH/IPPK issue with the Governor, and the heads of both Kanwil and Dinas Kehutanan (APHI 2000). At APHI's June 29 meeting in Surabaya, the Governor publicly called on the head of Dinas Kehutanan to instruct heads of CDK throughout East Kalimantan to: 1) stop issuing 'Letters of Recommendation' for HPHH and IPPK permits under consideration by the district governments; and 2) not release log transport permits Surat Keterangan Sahnya Hasil Hutan (SKSHH) for wood that had been harvested under HPHH or IPPK permits. At the Concessionaires' Association's August 9, 2000 meeting in Samarinda, the Governor gave a similar instruction directly to the heads of the CDK. Inhutani officers interviewed later that month were skeptical, however, that such directives would have much effect on the behavior of the branch offices of the Provincial Forestry Service, as the government's decentralisation process had seriously weakened the formal chain-ofcommand. According to one informant:

The CDKs are supposed to report to Dinas Kehutanan, which in turn reports the Governor. But the CDKs are now scared of the Bupati's ('takut sama Bupati') because they know that they will soon be reporting to him. Many of CDK's decisions are now based on what the Bupati wants.... Unfortunately, many of the CDK's decisions are also being influenced by 'envelopes' [i.e. informal payments]. ${ }^{59}$

In their efforts to maintain control over their concession sites, Inhutani officials have argued that the allocation of IPPK permits in areas designated as HPH timber concessions poses a vital threat to the future of sustainable forest management in the region. Specifically, they point out that the overlap between IPPKs and HPHs means that areas previously classified as Permanent Production Forest are now being slated for conversion. In many instances, the IPPKs have apparently been assigned for areas that correspond to some of the most valuable 
stands of commercial timber within a HPH's concessionary boundaries. According to the unit manager at Inhutani II in Malinau,

The IPPKs are being placed in areas that still have lots of commercial timber. In fact, the areas assigned to CV Hanura [the IPPK recipient] directly overlap with some of our richest secondary stands. It's almost certainly the case that somebody on the inside showed the $\mathrm{CV}$ where these were, as the IPPK permits often directly follow the borders of particular cutting blocks. We logged some of these areas in $1988 / 89$, so the trees are now quite big. However, in accordance with the Indonesian Selective Cutting System (Tebang Pilih Tanam Indonesia or TPTI), we have been waiting to reenter those areas until the 35 year rotation is up. If the $\mathrm{CV}$ goes into these areas, they will cut everything. ${ }^{60}$

On a related point, Inhutani officers claim that the allocation of IPPK licenses within HPH concession areas has drastically undermined the incentives for HPH-holders to employ sustainable management practices in other parts of their concessions, as well. They emphasized that without legal certainty ('kepastian hukum') and a secure business environment ('kepastian usaha'), it would make little sense of HPHholders to make any significant expenditures associated with sustainable forest management. As one Inhutani official put it,

A significant portion of our firm's revenues each year are spent on selective felling, enrichment planting, and managing the concession area in accordance with the criteria stated in the HPH contract - not to mention RIL (Reduced Impact Logging). Why should we continue carrying such costs if Pemda is going to allow IPPK-holders to cut whatever wood we leave standing?

Another informant stated that unless HPH boundaries were recognized by the district government, HPH-holders would be "forced" ('terpaksa') to abandon the TPTI selective cutting guidelines. To do otherwise, he asserted, would effectively mean that the HPH concessionaires were simply leaving commercially valuable timber "to be taken by other parties" ( 'untuk diambil oleh pihak lain'). ${ }^{62}$

Officials at both Inhutani I and II speculated that within the current political climate, their companies' access to continued timber profits over the long-term will ultimately depend upon finding ways to share benefits more directly with the regional governments and with local communities. To accomplish this, the Inhutani's formulated a strategic plan in mid-2000 aimed at establishing a number of joint ventures to manage individual HPH concession areas, Industrial Timber Plantation (Hutan Tanaman Industri or HTI) sites, or wood processing facilities. ${ }^{63}$ Each 'Strategic Business Unit' (or SBU), as these ventures are called, would involve a division of equity shares among the Inhutani, a private sector operating company, Pemda, and local communities or a cooperative. In late-August 2000, Inhutani I and II signed a memorandum of understanding (MOU) with East Kalimantan's provincial government which outlined the terms of collaboration for four pilot SBUs, one of which would operate an Inhutani HPH site in Malinau. At that time, Inhutani officials in Malinau and Tarakan were confident that similar MOUs would soon be signed with the district governments and local communities near the concession site. They also indicated that they believed other HPH-holders would soon be entering into similar agreements with the district and provincial governments, and with communities located near their concession areas.

In interviews in August and September 2000, these same Inhutani officials reported that their companies had also sought to communicate directly with the IPPK-holders and the communities that the new investors are supposedly working with. The manager of Inhutani I's Tarakan unit reported that his company had proposed to some communities that they work with Inhutani rather than the IPPK-holder, and that Inhutani would, in turn, pay a higher per unit fee than the new investor. ${ }^{64}$ 
At that time, the communities had turned down the offer. Officials at Inhutani I also indicated that they had approached the IPPK-holders to discuss the possibility of working together to exploit timber from the areas in question. The companies holding the IPPK permits were then reportedly reluctant to enter into any formal discussions with the Inhutani's. More recently, however, unconfirmed reports have emerged from both Malinau and Bulungan suggesting that the Inhutani's may have established informal partnerships of this sort with some IPPKholders. In Malinau, for instance, CV Hanura is said to be using the same contractor (PT Bina Benua) to manage its IPPK timber harvesting operations as Inhutani II uses at its surrounding concession site. Moreover, Inhutani has agreed to allow logs harvested from CV Hanura's IPPK site to be transported over Inhutani's road. Some observers have speculated that this may be indicative of a profit-sharing arrangement between the three companies - CV Hanura, PT Bina Benua, and Inhutani II - as the logs are harvested and transported from the HPH and IPPK sites by the same set of actors. ${ }^{65}$

\subsection{COMMUNITY CLAIMS TO LAND AND FOREST RIGHTS}

Provisions for the recognition of customary or ' $a d a$ ' lands in Indonesia's revised Forestry Law, or Undang-undang (UU) No 41/1999 and a decree by the Minister of Agrarian Reform (Kepmen No 5/1999) have opened up new possibilities under desentralisation for local communities to claim rights to forests resources. Because district authorities are now allocating rights to forest and land, local people can more easily gain access to decision-makers and decisions can be made more quickly. Unfortunately, the criteria and legal basis for determining land rights have been unclear. Overlapping claims and conflict have increased dramatically, without the necessary institutional capacity for resolving them being developed at the appropriate levels of government.

\subsubsection{Under the New Order Regime}

Rights to land and forest in Malinau historically have been determined by a combination of customary agreements among local communities and by formal laws and contractual arrangements driven by the center. Customarily, neighboring communities defined communal territories through agreements between leaders. ${ }^{66}$ Through the 1950 s, groups of families moved to a new location as needed (often because of disease, hard times, the search for more fertile land or family differences), based on whatever political alliances or power they might have with (or over) groups claiming a territory. Freedom to move declined dramatically however with government efforts to register and resettle people in the 1960s and 1970s using the model of the Javanese village or 'desa'. The government formally recognized settlements as villages through decrees issued by the Bulungan district leader, although most groups that received such decrees had populations far smaller than the minimum threshold set by national law, and a number of Punan settlements were never formally registered. The boundaries of the registered villages have never been formalized through field surveys. Existing government maps of villages bear little, if any, relationship to current settlements and the territories they use or claim.

Despite the recognition of villages as administrative units, New Order policies promoted the belief that local people had no rights to the forest land or resources around them. These resources were rather at the discretion of the central government. Timber concession-holders became the primary broker of formal rights to forests in areas classified as 'Production Forest'. Concessionaires sometimes negotiated directly with villages to determine where shifting cultivation and small strips of village forests (hutan desa) could occur. Concession-holders also gave rights to other parties, such as the Bara Dinamica Muda Sukses coal mining company that acquired the rights to excavate forest land in Long Loreh, Langap and Tanjung Nanga. In the protected forests of 
what is now the Kayan Mentarang National Park, the Provincial Forestry Service and, since 1990, also the World Wide Fund for Nature (WWF) Indonesia Programme have been the main parties with responsibility for informing and guiding local people about their rights and how to comply with national conservation objectives, although the degree to which they have achieved this has been mixed. WWF has worked more directly with local people, while the provincial government rarely had any presence in the area. ${ }^{67}$

Regardless of the New Order government's efforts, the remoteness of the region ensured that national policies were difficult to implement. Therefore, villagers operated under a dual system of rights. For the most part, they used the forest as they always had and observed customary traditions regarding access to forest and land, as described above. Only where there was direct conflict with HPH timberoperations, the coal mine, or a conservation effort like the enforcement of a no-hunting rule among local people employed by WWF staff were national interests more visibly imposed. With police or military officers usually hovering nearby (except in the WWF activities), villagers generally felt they had no alternative but to comply with national laws and regulation. Nevertheless, field staff of timber concessions acknowledged that some compromises were necessary on their part, as it was impossible to enforce rules about no burning or hunting. One official mentioned that it was more practical to allow local people to maintain their livelihoods than to prevent them from engaging in such practices.

During this time, battles between those seeking to extract resources (concessions, illegal loggers, mining companies) and communities for access and control to resources were fought on the ground through political alliances, intimidation and vague references to government policies. The precise legality of any of formal claims (berita acara) used by the state and concessionaires remains unclear and perhaps will never be known. Verbal agreements between local leaders about boundaries between village territories are difficult to verify and some of the original parties are now dead. Existing documents suggest that it was (and still is) common for signatures to be attached from other documents or solicited on false premises. The lack of access to many documents in government archives makes it difficult to investigate whether appropriate permissions and procedures (e.g. berita acara).

\subsubsection{Adat Unleashed}

Regional autonomy and decentralisation have led to several key changes. With the recognition of adat rights in the recent forestry and agrarian reform policies, local communities now assume that customary rights are no longer part of a 'dual' system where state rights superceded local rights, but rather rights that can be formally acknowledged. They are acting as owners of the land and forest they have traditionally used, even in interactions with government and outside parties. Local people note that police rarely accompany officials anymore when they visit villages located in and around forests. There is a widespread perception that the era of repression has ended, and that forest communities are now 'bebas' (free). Participatory mapping activities by $\mathrm{WWF}^{68}$ and CIFOR have provided tools for making land claims and have added to the general impression that villages can now formally claim rights in their territories. One local person said 'Once we produce our map, that is it, the land is ours.' As a result of a Governor's decree in 2000, villagers are also now filing compensation claims for timber previously cut in their area by HPH timber concessionaires. The way adat land is being defined and used has become one of the key determinants of how resources are allocated on forest lands.

In addition, opportunities to re-define villages into more locally meaningful units have opened the door for Malinau communities to try to reorganize existing allocation of lands. Three related trends have been taking place. First, groups are making claims based on adat. Ironically, these claims have often been aimed at securing recognition of existing or former 
village (desa) boundaries and negotiating to expand those boundaries. For a few influential or ambitious individuals, like the customary leader of the Merap in the Upper Malinau River, claims have been made on more encompassing areas (see discussion below). Second, some groups are seeking to use the re-definition of villages as an opportunity to remove unwanted neighbors. In some cases, those being targetted for removal arrived only 30 years ago, yet they have been more enterprising and economically successful than groups that are indigenous to the region. Third, local government is interested in rationalizing settlements to cluster groups in one location as one village, ostensibly to provide more efficient distribution of resources to a smaller number of settlements.

The recent allocation of IPPK forest conversion permits and the potential to secure compensation from companies involved in logging or coal mining have increased the incentives for local groups to make these claims. Although competition for resource claims existed historically over birds nest caves and, since 1996, over areas to be mined, the availability of IPPK permits has raised this competition to new heights. In addition, the Governor of East Kalimantan issued a decree in May 2000 (SK No 20/2000) instructing HPH concession-holders to pay compensation to communities for timber cut since the mid-1990s. Compensation levels were set at the rate of Rp. $1,500 / \mathrm{m}^{3}$ for meranti and Rp. 1,000/ $\mathrm{m}^{3}$ for mixed timber for the period $1995-1999$ and Rp. 3,000/ $\mathrm{m}^{3}$ for meranti and Rp. $2,500 / \mathrm{m}^{3}$ since $2000 .{ }^{69}$ As a consequence, people representing various groups or interests have scrambled to make claims quickly. These claims are being made in an atmosphere of confusion and fierce competition amidst a general lack of information about the legal basis for village boundaries or rights to forest resources. Government officials and logging companies have been willing to endorse adat claims to help process applications for the IPPK permits. As one official explained, however, Malinau's district government cannot turn down IPPK applications that fail to meet technical criteria for fear that communities will protest.

\subsubsection{Defining Adat Claims}

How the terms 'adat' and 'village' are defined in Malinau will having enormous implications for how land and forest benefits will be distributed under decentralisation. What do adat claims mean in Malinau? There is no single or easy answer. Legal provisions offer little guidance $^{70}$ and few people in the district are even sure of what the laws say. The implementing regulation for 'hutan adat' in the revised Forestry Law (UU No 41/1999) was never passed. As of January 2001, the districts have had the authority to pass their own regulations, although Malinau's government has not yet had the time to do so. Similarly, the implications of Decree from the Minister of Agrarian Reform (Kepmen No 5/1999) are unclear at the district level. Legally, the only operational local reference to adat occurs under a district regulation inherited from Bulungan on the 'Strengthening, Preservation, Protection, and Development of Adat Practices and Institutions' (Pemberdayaan, Pelestarian, Perlindungan dan Pengembangan Adat Istiadat dan Lembaga Adat) which is currently under review by Malinau's Legislative Assembly. ${ }^{71}$ This regulation, however, offers no criteria for designating adat lands, no process for doing so, and no means for resolving conflicts.

Among people in the villages, most interpret tanah adat as either 'traditional' lands where a group came from or the land where they currently live. Adat units are defined first by ethnic group and second by location. They usually fall along existing village territories or the territory of a higher-level customary leader, as in the case of Impang Alang, the Merap leader on the Malinau River or Anye Apui, the Lepo' Ma'ut leader on the Bahau River. In the race to grab land, some villagers are using previous adat rules about ownership being conferred through cutting the forest (merimba) and tree planting to make claims to even larger areas for their villages or for individual families. However the introduction of specific legal meanings of adat associated with wilayah adat, masyarakat adat, lembaga adat, tanah adat and hutan adat under decentralization 
policies have now become intermeshed with the vernacular usage, resulting in further confusion. No one is sure if the government still has any claims to forest. Many villages are increasingly of mixed ethnicity.

Discussion among local communities about the re-definition of villages and possibilities for claiming rights has been limited and has raised more questions than answers. Informal debate has concentrated on the length of time a group needs to have been in an area to be able to claim adat rights. Most local people are not even aware that the definition of village is up for legal revision. WWF, Plasma (a Samarinda-based NGO) and CIFOR have sporadically facilitated discussion or distributed information about new policies, but the information conveyed has not always been reliable. When community members asked the Inhutani representatives and other concession holders in a CIFOR-sponsored multistakeholder dialog in December 2000 what hutan adat was, they declined to respond. The local land registration office in the same meeting offered the advice that people could now apply for certificates of land titles, even though nearly all the land in the Upper Malinau is technically state forest land that has been allocated to HPH timber concession-holders. Government officials have urged repeatedly that this is a 'masa transisi' (transition period) and that people have to be patient for things to be worked out.

Overlaps among adat claims have complicated matters further. Descendents of aristocratic Dayak and Sultanate families that once controlled large areas of Malinau have sought to make sweeping adat claims encompassing several smaller village territories and even overlapping with each other. Some of these people have not been resident in their self-proclaimed territorties. One Lundaye individual attempted to establish himself as the adat leader for the entire Malinau district, although the Merap adat leader and sent a letter to the district government in protest and the request was never approved. Because of the historical migration patterns of the local ricecultivating and hunter-gather populations, any one location in the district has most likely been the past home of at least two different ethnic groups. Using historical presence in an area as a criterion for making land claims is thus problematic to apply fairly.

Groups that migrated during the resettement era in the 1960s and 1970s feel especially vulnerable to definitions of adat based on historical presence, especially since many have since given up their original lands. Ethnic groups like the Merap, Abai, Tidung, Berusu and some Punan that settled earlier in the Malinau area have from the start claimed prior rights to 'their' wilayah adat. During the course of the year 2000 they became more outspoken about their claims and have sought to persuade others to recognize these rights. On the Malinau River, four villagesSentaban, Setarap, Gong Solok and Langapargue that they were first in the area and that the others asked permission from them. This argument has had mixed results depending on the political strength of the villages. In the case of Sentaban and Setarap, neither had the political connections or strength of numbers to win their case and Setulang has been able to maintain its claims. In the case of Langap, a small neighboring Punan village was pressured to give up its land rights completely and another neighboring Punan village was forced to accept boundaries dictated by Langap. The more politically connected and larger Kenyah villages of Tanjung Nanga and Long Loreh negotiated boundaries that gave these neighbors reasonably large territories.

Pressure by these earlier residents has resulted in sharp conflict among a number of villages (Setulang and Sentaban, Long Rat and Langap). Most consider the debate and process of designating boundaries still unfinished. Government officials have confessed that historical claims would be difficult to accommodate without alienating a large groups in the district. Indeed, the largest settlements along the Malinau River (Setulang, Loreh and Tanjung Nanga) are composed of Kenyah families that settled in the 1960s and 1970s and which alone constitute a population of nearly 2000 . 
In many locations, the national government's resettlement program also resulted in clusters of several different ethnic groups or subgroups living together, having separate village designations. This raises questions about whether such groups should claim adat rights together or separately in their current territory, or whether they should claim rights in their previous place of residence. Some villages have chosed to claim land together (Gong Solok and Punan Gong Solok, Long Adiu and Punan Adiu, Paya Seturan, Punan Rian, Setarap and Punan Setarap ${ }^{72}$ ), while most over time have opted to make independent claims (Mirau and Halanga versus Laban Nyarit, Long Sengayan, Pelancau and Long Loreh versus Bila Bekayuk). Others have chosen to make claims in previous villages (Pelancau, Metut, Long Rat, Bila Bekayuk, and ten Punan villages in the resettlement village of Sembuak). The smaller, usually Punan communities have become increasingly reluctant to claim lands together with other villages in one location, feeling that this would expose them to the risk of further domination.

Punan groups face the additional difficulty that they have historically not defined their space in terms of territories. Most Punan groups have moved repeatedly and depended on vast areas of forest because of their nature as a semi-settled and nomadic hunting gathering group. Many have historically lived and moved in association with Merap, Tidung, Abai or Lundaye 'sponsors.' A few Punan settlements face the additional problem that they do not hold formal village status and therefore are categorized as inhabiting the villages of other (usually Punan) groups. How does one define the adat areas of Punan groups under these circumstances? Is it possible or desirable to provide adat use rights in addition to ownership rights? Will the codification of adat rights unfairly disadvantage groups who have maintained a nomadic lifestyle by making them legally landless?

Despite the confusion about the term 'adat' and its implications, local communities, district government agencies and even companies in practice are treating registered villages as the most common unit for adat claims. Three pieces of evidence point to this conclusion. First, in 1999, when villagers were asked in the mapping project facilitated by CIFOR what they wanted to map, they unanimously responded that mapping their village boundaries was their highest priority. Since 1999, 22 communities of the Upper Malinau have mapped their boundaries based on registered village territories. Second, timber compensation claims have been based on village boundaries. For example, Langap requested compensation of $\mathrm{Rp} 225$ million (30,000 cubic meters of wood $\mathrm{x}$ Rp 1,500 x 5 years) for wood cut during the period 1995-2000 in their village boundaries. Residents of the Liu Mutai settlement, a Punan group registered to the Pelancau village but living within Metut village boundaries, were not allowed to make compensation claims, even for timber activities adjacent to their settlement. Third, the district government has been issuing IPPK forest conversion permits almost entirely to villages, and referring to these villages in terms of 'tanah adat,' 'hutan tanah adat,' 'tanah adat masyarakat,' 'tanah masyarakat adat' 'hutan adat,' 'hutan milik' and 'tanah warisan.' Using existing villages territories has probably been the most expedient and most conflict-minimizing means of allocating adat rights.

At least until May 2001, however, no claims to land or forest appear to have been finalized legally, and an atmosphere of confusion and competition still reigned in Malinau. Indirectly, however, the IPPK licenses have become a critical instrument for acquiring land and forest tenure. Every IPPK has included in its title a statement about the location of the land where timber is to be harvested. In 32 out of the 38 IPPKs that had been issued in Malinau by that point, 'ownership' and location were conflated, such that the licenses state that permission was granted, for example, 'in the location of the the land of the customary society of Sesua village' ('di lokasi tanah adat masyarakat desa Sesua'). The IPPKs have provided villagers with enough confidence to feel that these rights supercede those of the timber concessions. Villagers in Langap, people used an IPPK license granted to CV Hanura to procure benefits from cutting timber in the Malinau 
concession of Inhutani II. Most IPPKs have been located within a particular village, although a few IPPK's have also been issued enclaves within village territitories. ${ }^{73}$

\subsubsection{IPPK Benefits for Local Communities}

Logging companies that have secured IPPK forest conversion permits typically promised to provide four types of material benefits to community members. First, they have often made donations of rice and basic food stuffs, agricultural tools, clothing, or other material goods when they first enter a village to negotiate a timber harvesting agreement. They also have promised donations of such material goods, including short-wave radios, outboard motors, roofing material or rice mills, and infrastructural improvements, including the construction of new roads, health care facilities, offices and schools.

Second, the timber companies have agreed to provide community members with a set fee for each cubic meter of wood harvested. These fees, which are negotiated on a case-by-case basis, are known to range between Rp 5,000 and Rp 40,000 per $\mathrm{m}^{3}$ of roundwood.

Third, the companies have hired local people as laborers to cut the timber and have paid them daily wages for this work. Wages paid for chainsaw and tractor work have been based on units of timber produced. Wages have ranged from $\operatorname{Rp} 2,500$ to 3,000 for chainsaw operators and around $\mathrm{Rp} 2,500$ for tractor operators.

Fourth, IPPK permit-holders have generally agreed to finance the development of cash crop plantations on the areas logged once these have been cleared. Local entrepreneurs involved in these negotiations indicated that the logging companies often allowed community members to choose whichever kind of crops they wished. Among communities near Malinau, several have chosen to have the companies establish rattan, coffee, cocoa, or pepper gardens when the specified areas had been cleared. ${ }^{74}$ In some cases, the company's willingness to make such investments has been tied to future purchasing agreements for once these products are ready for harvest.

The extent to which such benefits have been realized is another question. In many cases, members of forest communities have indicated that under the New Order regime, they received little if any benefits from forests associated with HPH timber concessions. Many reportedly find IPPKpermits attractive because they expect to be able to enjoy significant direct benefits from forests for the first time. Under decentralisation, they are also often dealing with companies involving people they know, frequently including relatives. ${ }^{75}$ Many apparently feel that their interests are protected by signed and notarized contracts (surat perjanjian). Yet increasingly, these contracts have included absurd agreements or have been unfulfilled. Consequently, community protests against IPPK logging operations since mid 2001 have been on the rise.

Because of the eagerness to capture benefits, their lack of information and inability to control the logging companies, communities have often been vulnerable to companies' abuse of contractual agreements. In the creation of the agreements, communities have been anxious to grab whatever opportunity they can, and they frequently do not know or fully consider their options. In many cases, forest communities have accepted the first offer companies provided to them. In the enforcement of IPPK agreements, the absence of legal support has meant that contracts have carried little weight. Although these problems have been common elsewhere in Indonesia where forests were cleared by companies for perennial crops like oil palm, this is the Malinau communities' first experience with the unreliable and unaccountable behavior of the IPPK holders.

Examples of abuse by IPPK-holders are numerous. After operating for about six months and removing wood from the village of Bila Bekayuk, CV Sebuku Lestari had not paid any of the promised benefits as of May 2001, or replanted the cleared area as promised in their 
Box 1. Benefits Promised by IPPK Holders: the Case of CV Gading Indah

In the village of Setarap, CV Gading Indah acquired an IPPK permit to clear 1,200 hectares of forest in two blocks, situated on either side of the Malinau River. According to villagers, the company promised by a notarized contract to provide the following benefits to local community members:

- Advance payment of 125 million rupiah

- Assistance in creating wet rice fields

- A road connecting the village to the main access road

- Assistance in establishing perennial tree crop plantations

- Construction of a church

- Assistance in leveling land for expansion of the village

- A fee of Rp. 40,000 for each cubic meter of timber harvested

joint contract (see box). In the village of Adiu, community members protested in November 2000 when their advance payment of Rp 50 million was not received from CV Wana Bhakti, after a month of operation. Chainsaw operators from Adiu had also not been paid yet. In October 2000 , youth from Setarap, protested because the company had employed only non-locals, despite promises otherwise. They also protested that the distribution of the advance payment funds was not transparent or fair and accused the village leader of not being honest about the benefits he, himself, was getting from the deal. Reflecting a different problem related to land claims (see discussion below), the contract between Sengayan and CV Putera Surip Widjaya states that the company has the right to an area of 35,000 hectares, but the total area of the joint territory in the Long Loreh settlement (where Sengayan is located) is only 12,000 hectares! In another case in Bila Bekayuk, a local man involved in negotiations with the company was not even sure of how much one hectare was. Local communities will remain disadvantaged under these circumstances until more fair negotation and enforcement mechanisms can be worked out.

\subsubsection{Has Space Been Created For The Communities?}

The use of IPPK permits appears to be producing an informal codification of land rights in Malinau and establishing a precedent for allocating adat rights primarily on the basis of existing village boundaries. Yet, because of the diverse appellations used (see above), they are doing so in a way that suggests there is no consistent understanding of how land claims should be justified or which rights are conferred.

It is also not clear who is really benefiting from the adat claims asserted through IPPKs. Although it is reflective of decentralization that communities' permission is sought and benefits are being offered, one might question whether communities are sufficiently informed and protected to ensure that they are not, in effect, signing away their rights and foregoing longterm benefits through IPPKs. One government official informed us that the ownership claims were necessary in the application for the IPPK permit for the Forestry Department to allow commercial timber harvesting in areas classified as 'Protection Forest'. Some have hinted that moves to claim adat lands may be a measure to reduce central government claims to land in order to free up forest land for conversion to uses that are more economically lucrativefor district-level stakeholders. Others have speculated that people are anxious to acquire land ownership though IPPK permits and conversion of forest because applying for a land certificate through the National Land Agency (Badan Pertanahan Nasional or BPN) is too costly and time-consuming. At the village level, negotiations with the companies and government officials have often been done by only a handful of village leaders, who usually request a disproportionate portion of benefits for themselves or their families. 


\section{Box 2. Village Experiences with IPPK Permits}

The two cases below demonstrate contrasting experiences with IPPK forest conversion permits. They show the techniques companies used to negotiate IPPKs and what kinds of benefits were received by forest communities. The contrast highlights the role of ethnicity, information and political influence in affecting the degree to which communities are benefiting from the economic opportunities provided by decentralisation.

Bila Bekayuk is one of the four villages located in the settlement of Long Loreh. The population of Bila Bekayuk consists of Punan Tubu who migrated from the Tubu River to the Malinau River in the early 1980s. Until recently, all four villages had decided to claim their 12,000 ha of adat land as one unit and had mapped it as such in February 2000.

In March 2000, however, villagers in Bila Bekayuk, particularly the Punan, began discussing the offer of a local entrepreneur to establish cash crops. The topic generated heated debate among the four villages of Long Loreh, with many skeptical about the entrepreneur's plan. The entrepreneur tried to convince villagers that he was interested in helping the economic development of the Punan and brought other Punan and Dayak people, as well district government officials, to discuss the matter with the people of Bila Bekayuk. In July 2000, the other three villages recognised that Bila Bekayuk would proceed with the plan to establish cash crops and decided to divide the village area into four parts. Each part would be fully controlled by a village, and people from other villages would even if they live in Long Loreh have to ask for formal permission to enter.

Before this decision was made, however, the entrepreneur had already obtained the necessary letters, including an IPPK permit for 1,050 ha and government permission to bring in heavy equipment. Two roads were cut into the area to be logged. According to one of the Bila Bekayuk men involved, they were only going to allow the entrepreneur to cut an initial 100 ha that would next year be converted into coffee and candlenut gardens. In an interview with CIFOR researchers, however, the same person asked 'How much is actually one hectare?' On $13^{\text {th }}$ August the village head of Bila Bekayuk said they also had no agreement in writing stating the obligations of the entrepreneur, or the conditions pertaining to the establishing of the cash crop plantation. Logging occurred in an area of approximately 1000 hectares (according to the agreement) between about July and December 2000. The logging company left suddenly at the end of the year after the logging was completed, without any further communication with the community. Local laborers were left without their wages paid. When the village tried to contact the entrepreneur, they found that he had fled. One villager saidin retrospect, We cry when we think of what has happened and now urges everyone to take caution in negotiating with IPPK seekers.

Langap is a village about midway along the Malinau River (at the confluence with the Ran River) with close to 400 inhabitants mainly of the Merap ethnic group. The Merap of Langap have resided in this area for a long time (according to oral history eleven or thirteen generations, depending on the source of information); however the village location has moved several times. They have been powerful and well connected with outsiders and have been relatively prosperous. They claim a huge village area of over 35,000 ha, although parts of this area are also claimed by other communities. A large part of the Inhutani II Subunit Malinau logging concession is located within the Langap village area.

It seems that only as 'late' as June 2000 the people of Langap started seriously to investigate the possibility of exploiting their forest. During the initial discussions, during a village meeting attended by about 30 persons, the villagers agreed to hand over the rights to 30,000 ha of their adat land to the entrepreneur. The entrepreneur in return promised to establish cash crop farms. The deal was almost sealed, but one community member was shocked by the area promised to the company. This individual managed to talk the people into drawing up an agreement covering only 15,000 ha., which would be 'converted into coffee and black pepper farms for the use of the villagers.' The permission for the land was granted before any signed agreement about the obligation of the company was finalized. The entrepreneur meanwhile promised to pay only Rp. $5,000 / \mathrm{m}^{3}$ for the timberharvested, one of the lowest figures so far promised to villagers in the Malinau area.

Only in hindsight have Langap residents become worried. The son of the local customary leader (Kepala Adat Besar) visited Langap in in early August while he was still a member of the DPRD Legislative Assembly in Bulungan ${ }^{76}$, after he had been on a tour investigating IPPK operations in Bulungan and Nunukan regencies. He described experiences in nearby Sajau, Sekatak, Salimbatu (in Bulungan District) and Sebuku (in Nunukan District) where similar schemes have been implemented. He said 'We thought that logging companies (i.e. HPH-holders) were bad, but this is far worse.' However, members of the community noted that the entrepreneur had already threatened to claim Rp 2 billion rupiah in compensation if the scheme fell through. This intimidation tactic of the entrepreneur worked. The entrepreneur also promised to provide a free 1.8 ton of rice to the village, presumably to encourage the community to pressure their leaders to support the scheme.

Complicating the case further, the area to be logged was on the Inhutani II concession In the agreement between the villagers of Langap and Punan Rian and the company,dated 20 May 2000, with the entrepreneur it states that the community guarantees that the land is not under dispute. Thus far, commuinties have received 2.5 tons of rice, 2 bushcutters, 25 million rupiah to establish a cooperative and a second hand truck. benefits and are negotiating a second contract with another company for logging in their territory, also on the Inhutani concession. 
Throughout this process, conflict has increased. Most of all stakeholder groups have seemingly been trying to figure out a way to make or increase their own claims. A trend is occurring among villages to claim locations where they had previously settled (Nunuk Tanah Kibang, Pelancau, Sengayan, Metut, Liu Mahan ${ }^{77}$ ). These conflicts frequently amount to struggles over the immediate economic goods at stake, either from timber harvesting, the possibility of compensation claims, or the availability of fruit and perennial trees for consumption or cash. The increased economic gains made possible by decentralization have therefore also helped to escalate conflict over land and forest claims.

Where informal agreements over boundaries supposedly have been reached, they have been short-lived or partial because both villages did not take part fairly in the boundary marking process. Differences of opinion have also frequently existed among members of a single village. No criteria have been promulgated by the district government or among villages for establishing what constitutes a fair agreement or how conflicts should be settled. It has been common instead for village leaders and elders to often negotiate in a nontransparent way without the involvement of the rest of their own village. Decisions have often been justified on the basis of small meetings. When asked about the procedure to obtain permits for local logging activities, the sub-district head said that if the 'people' approve (that is, if a letter is produced with the signature of the village head and the adat leader) he automatically provides the recommendation to the next level. He explained, 'I can not act against the wish of the people.' Decentralisation has thus encouraged attention to local people'saspirations, but the process for identifying those aspirations has been left unspecified. In addition, the individuals with the authority to make decisions on behalf of the community are often different from the ones with the knowledge of boundaries on the ground. In a few cases, boundaries were marked before any even nominal agreement had been reached between villages. Where conflicts have occurred, some Punan and other groups have sought to resolve the discord by simply moving (Mirau, Halanga and Long Rat) or at least threatening to move (villages in Respen Sembuak).

The Punan, as a politically marginalized, nomadic hunter-gatherer group, have been especially disadvantaged in negotiations about boundaries and benefits. Participation of communitymembers is often limited, as a large contingent of the population of a village is often in the forest. It is rare to meet all inhabitants of one community in the settlement, as happened in Mirau in mid-2000 during a boundary negotiation. Inhabitants of Mirau returned from a forest product collecting trip and immediately pulled up border markers that had been just put in a place by a joint Mirau Laban Nyarit mapping team. Where Punan have shared decision making with other ethnic groups, they face the additional burden of prejudice, smaller numbers and lack of political clout.

Even where negotiations have occurred and agreements have been stable, villages have had limited success in enforcing them. IPPK activities that involved cutting roads through the territory of other village have in at least three cases (Setulang, Laban Nyarit and Long Loreh), removed timber or destroyed valued fruit trees generating anger among villagers with acknowledged claims to these lands. While local communities have tended to casually monitor IPPK activities, there have been considerable opportunities for heavy machinery and chainsaws to damage large extents of forest unobserved. The absence of better monitoring, strong NGOs, ${ }^{78}$ media or other 'third' party actors in the area has meant that companies have often worked without critical evaluation.

\subsection{Coordinating Land Use}

In Malinau, the rapid increase in timber extraction and the staking of land claims brought about by decentralization has occurred with little coordination. Because of the speed of events, there has been little opportunity for careful planning of long-term resource use. Instead, people appear to be operating according to free market principles, guided by immediate 
economic incentives and the readiness of 'investors' to enter the region. Local conflict about land and forest use has increased.

In this heady atmosphere of the boom economy, officials and villagers seem to have made improving land use coordination a secondary priority. At the district level, spatial planning and technical advice about forest management have been noticeably absent. Impact assessment and conflict resolution measures have been informal and weak. Through mid-2001 when this study was conducted, there was no conservation strategy for the district and Kayan Mentarang National Park was viewed more as a burden than an asset. At the village level, decisions about forest exploitation have often been negotiated among only a few individuals. Only a handful of villages have begun to identify their own land use priorities.

The Malinau district thus faces the dilemma of how to continue to generate revenues through the exploitation of forests and other natural resources, while also maintaining the integrity of the resource base for the future. District officials also most cope with rising conflict among different populations in the district. The following sections review efforts that have thus far been made to analyze how longer-term and more balanced resource use strategies might evolve.

\subsubsection{District Spatial Planning}

Procedures for spatial planning under the New Order regime gave central and provincial government agencies authority to determine forest boundaries and functions. A 1999 report by NRM - the USAID-funded Natural Resource Management program states that BAPPEDA in East Kalimantan saw itself as more of a funnel of information, with the kabupatens providing a service role to the provinces, than as a proactive planning body. BAPPEDA's role was to compile decisions made by other agencies. The Governor was responsible for resolving conflicts, often in consultation with the Ministry of Home Affairs and other relevant ministers, with the strongest party winning. Actual land use depended more on the permits issued by agencies and executive officials than on plans. As a result spatial planning has been more of a paper exercise than a tool to encourage analysis and debate of appropriate land use practices. As such, the government's formal spatial planning process has historically done little to provide transparency and accountability in the coordination of land use.

With decentralisation, decision-making authority is now vested in district officials over the spatial planning process. This presents opportunities in that spatial planning is now likely to involve closer cooperation between government and communities; to better reflect local communities' interests; and to be conducted at a finer scale of resolution. The local BAPPEDA's are responsible for producing and coordinating five-year spatial plans among the different sectors for the region. Many of the challenges to good spatial planning remain the same, however. Unless these are addressed, spatial planning will remain a paper exercise. As elsewhere in Indonesia (NRM 1999), spatial planning in Malinau has been handicapped by:

- A lack of good field data;

- The tendency for private sector timber and mining companies to produce and use their own maps;

- The use of consultants to produce planning documents who have no accountability to stakeholders or the agency mission;

- Planning documents produced to fulfill deadline or contractual obligations rather than reflecting ground-level realities and stakeholder interests (i.e. documents are often photocopied from one region to the next);

- The lack of authority on the part of BAPPEDA to enforce plans, and the stronger influence of mining or forestry groups in making land use decisions;

- The lack of participation and information from communities or even kabupaten-level groups, including BAPPEDA; 
Malinau officials have found it difficult to visit the region's most remote locations and populations due to the district's limited infrastructure and resources, and the diversion of attention created by the establishment of the new kabupaten. Decentralization has also brought the encumbrance of a close-knit set of local political and economic networks and powerful local investor interests, suggesting that even greater challenges will be faced in creating a democratic land use planning or decision making process.

In Malinau, BAPPEDA officials reported in 1999 that they did not physically have any maps of the new kabupaten, even though a Forest Land Use Concensus (Tata Guna Hutan Kesepakatan or TGHK) map from the province existed. They did not have any mapping specialists. A comparison of village level census, economic and land use data available with CIFOR's own data showed considerable discrepancies. As a new and relatively remote kabupaten, Malinau's BAPPEDA office was classified as a 'Class C' facility, or one with the minimal offices and positions. With the need to set up the new government offices, BAPPEDA and others showed little interest until mid-2000 in spatial planning and until that time, were uncertain about how the spatial planning process might work. In discussions about land use planning, the aspect of greatest interest to several government officials was in gaining access to community maps, presumably for their use in negotiating timber extraction. By mid-2000 BAPPEDA had acquired a copy of the provincial TGHK map.

When the district government did initiate its spatial planning process, the initiative lacked credibility and seemed to falter for lack of interest. In mid-2000, a consultant with family ties to the BAPPEDA project leader prepared a team and a proposal detailing plans for how the spatial planning process should occur. The proposal was reviewed in a multi-stakeholder meeting in September 2000. The meeting was conducted hastily, however, and lacked participation from the Bupati's office. No community representatives or subdistrict leaders attended. No further public reviews or discussion have taken place, and the report was not made publicly available, at least through mid-2001.

Schedule and budget considerations reportedly constrained the spatial planning team's field work. The process of producing a draft plan was to be completed by November 2000, with a report available in December; a revision process was expected to occur in 2001. Because of the rushed schedule, the team intially intended to undertake only two weeks more of field work in the remote regions of the kabupatenPujungan, Kayan Hilir and Hulu - with the team leader making the statement, 'We know the Malinau River areas already.' According to team's Terms of References (TOR), a scenario planning exercise was supposed to have been conducted, but as funds were limited this activity was cut. In the end, the report was completed without any field work having been done.

The process also lacked more meaningful and broad participation by district stakeholders in reviewing alternative plans and making recommendations, as would be hoped under decentralization. The proposal mentioned that the plan should reflect the 'aspirasi masyarakat' (communities' aspirations), however the activities planned did not involve communities or their representative bodies.

The articulation and discussion of technical criteria for land use decision making has been limited in the process observed to date. No criteria were discussed in the proposal, and the team leader appeared to lack familiarity with such criteria. In a casual conversation with CIFOR researchers, he stated his vision that 60 percent of Malinau should be classified as 'Protected Area', because there would inevitably be encroachment. He explained that this would leave a 50:50 balance between areas allocated for various forms of exploitation and use, on the one hand, and conservation, on the other. When questioned, he was non-plussed about how topography, land-use potential or national park constraints might affect this vision. 
Consistent with the overall tone of decentralization, a number of local people observing the spatial planning process over the last year concluded that the main interest of the BAPPEDA team appeared to be in assessing the economic potential of the region. The team leader also noted the difficulty of producing a spatial plan when (by 4 September 2000) 16 IPPK forest conversion permits had already been issued. The question was raised about to what extent BAPPEDA would have the authority to change the zoning of these lands.

Bupati Marthin Billa has stated his enthusiasm for engaging in the spatial planning process. A budget is available for mapping administrative boundaries, and the BAPPEDA office appears to be acquiring more information like recent satellite imagery. Discussion in a CIFORsponsored multistakeholder meeting in May 2001 showed that a number of groups, including the Inhutani state forestry enterprises, local communities, and district government officials hoped that the district would develop principles of land-use and a land-use plan in a transparent and participatory way before pursuing resource extraction. Officials have promised to withdraw the small-scale timber licenses to enable such a rational process, but no real action has occurred to stop the IPPKs, despite ostensible suspensions. Despite genuine good intentions, the pressures on Malinau for quick economic gain have been too high and distracting for district officials to undertake what has yet to be proved as more than a paper exercise.

Coordination between district planners and forestry technical advisors has been weak under decentralisation. As noted above, Malinau only began to assemble its own district forestry service in mid-2001. Coordination continues to be by default under the provincial government in the CDK Bulungan Tengah. Because the CDK is located in Tarakan, a two to four hour boat ride from Kota Malinau, its participation in district decision making has been limited. Its primary function appears to have been to provide the technical approval of IPPK applications, which has occurred, CDK officials confess, with little time or resources to conduct the field surveys that are supposed to accompany these applications. A number of IPPKs have been granted within protected forest zones, and most without field surveys. A CDK official explained that regional autonomy has raised community expectations. CDK has granted approvals to communities even on protected lands on the basis that these communities have claimed adat rights, which CDK argues provides a legitimate basis for exceptions. Informal incentives also encourage the bending of rules in the permit allocation process. CDK officials say they feel torn between trying to serve both industrial and community interests. One of the major gaps under decentralisation has been the lack of clarity about the role of these provincial bodies, especially vis-à-vis district agencies. CDK officials claim that they expect to play a significant role in coordinating cross-district forest management.

\subsubsection{Village Land Use Planning}

Although not required by law, land use planning at the village level is another key means of coordination. Villages within the Kayan Mentarang National Park have been most active in this regard, with facilitation from WWF. Since 1994, WWF has worked with people living in the park to identify zones for different levels of use and protection, especially the location of tana' ulen or protected forest areas. The villages have produced maps to this effect, although the stability of the agreements and their enforcement remain to be tested.

These efforts have occurred in addition to traditional practices of collective planning that focused on the location of shifting cultivation fields each year and the occasional setting aside of protected areas.

On the Malinau River, outside the national park, people tend to only meet with families planning to have adjacent plots to select shifting cultivation locations. Formal protected areas are more rare in the Malinau River area, perhaps because of the stronger presence of HPH timber 
concessions, as well as the weakening of customary practices (due to mixing of ethnic groups) wherein the aristocrats of Dayak communities often set aside and controlled protected lands. Although villagers appearto not share any single vision about desired longer term land use, villagers actively discuss among themselves which lands are appropriate for which use.

These discussions appear to have increased with IPPK activity. People in several villages explained to us their desire to see forest set aside for the short-term and long-term, as well as some forest set aside for shifting cultivation use and other forest for hunting and collecting of forest products only. There was, however, little agreement about what land use categories meant and how much forest should be set aside for specific functions. We observed community members using the term 'hutan adat' to mean alternately their entire village area, the forest within their claimed territory, or a protected forest. 'Hutan lindung' or 'protected forest' referred to no use according to some people, or limited use according to others. 'Hutan kas desa' was often used to refer to forest set aside for specific uses to benefit the community. Like district government, most communities seem to be giving first priority to securing economic benefits before determining their long-term resource plans. However, there has been a growing interest in planning land use, especially as distrust of IPPK permit holders has grown and more forest has disappeared. 


\section{CONCLUSION}

Decentralisation has encouraged an unprecedented race for claims to forest benefits and resources in Malinau. During this time, the new kabupaten has had a limited capacity to manage the resulting competition and conflict over forest resources. These circumstances, when taken together, suggest disturbing implications for long-term forest management and the well-being of groups likely to get left behind in the competition.

As demonstrated above, IPPKs have been a key instrument affecting these trends. With authority to grant small-scale timber harvesting and forest conversion permits, the newly founded district government has suddenly gained tremendous rights and responsibilities in relation to a valuable resource. The allocation of IPPK permits has allowed quick profits to be made from timber exploitation. These profits have created incentives for nearly everyone in the area-including district government officials, provincial forestry authorities, investors from Malaysia, local timber brokers, and forest communities - to seek to clear forest area rapidly. Consequently, licenses have been issued on lands with other designated functions, including areas classified as 'Protection Forest' or 'Production Forest' in an existing timber concession. There do not appear to be adequate controls over the amount of area to be cut, or effective monitoring of the impacts of logging now being carried out by IPPK permit-holders. Communities, government officials, industry actors refer to regional autonomy and a history of centrally-managed timber exploitation under the New Order regime to justify their shared lack of regard for these previous uses or users.

Similarly, the lack of clarity about adat lands and abuse of the opportunities to make claims have contributed to the atmosphere of confusion and conflict. Adat claims have often been more oriented towards carving up the spoils from rapid resource depletion or making demands for compensation for forest damage, than towards maintaining local identity and ties to a territory. Claims to forest and land are being made primarily through adat-based associations of a group with a particular territory and have been codified most noticeably through the participatory mapping and the issuance of IPPKs. Existing registered villages have frequently been the unit of these claims, and within-village claims to resources remain determined by customary measures, or in relation to deals with companies, which often obscure and dominated by a few people. With the widespread issuance of IPPK permits by Malinau's district government, forest communities have been enticed by small timber companies' offers of fees, infrastructural development, employment and luxury goods to enter into contractual arrangements for cutting timber in their areas. However, the fulfillment of contractual obligations has been uneven and several incidents of community protest have occurred. The legitimacy of these claims and their meaning in conflicts with other stakeholders remain to be tested. 
From this analysis of Malinau's experience in the last two years, we identify four main conclusions.

\subsection{RAPIDITY OF CHANGE}

The rapidity of change in the adminstration management of the region's forests is unlike any that the areas now encompassed by kabupaten Malinau have ever experienced. The geographic extent of impacts on the forest is potentially huge, with more than 50,000 hectares already scheduled for clear-cutting in the first year of dencentralisation. Moreover, these areas are scattered throughout several river basins. The prevalence of illegal logging and the quantities of heavy machinery being brought into the region suggest that the total area of deforestation will ultimately be even larger than that formally approved for conversion by the new district government. In the rush to secure immediate monetary profits from timber harvesting, the district's forest resource base is likely to be exploited much faster than either district government agencies or local communities are able to monitor or control. Large areas of forest will be fragmented, damaged and even cleared completely, quite possibly before effective measures can be taken to manage these processes. The institutions for administering Malinau's forest resources have only limited capacity to manage the pace and the intensity of environmental damage and social conflict that are now occuring. Many of these changes will be irreversible with long-term losses of biodiversity and negative effects on the livelihoods of forest communities, and pressures on the districts' economic resource base.

\subsection{FOCUS ON SHORT-TERM INCOME GAINS}

In Malinau, decentralization has created pressures and opportunities for revenue generation, but has not created concomitant controls for long-term resource management.
As a consequence, the pattern of timber exploitation established during the New Order period has been repeated at a more localized scale. Local stakeholders increasingly see the forest as a new source of significant income to be exploited over the short and medium term, not generally as a capital resource to be managed sustainably for its own sake. This exploitation appears to be guided by a free market-driven approach to generating immediate and maximum profits, and not by specific budget targets or a longer-term vision of economic development and forest management. Even with regards to the Kayan Mentarang National Park, kabupaten officials have placed more emphasis on how to turn the park into an asset through ecotourism than on the need for a protection strategy. Communities, especially, seem to not have an understanding that the forest might one day disappear, although their views are changing as they learn of forest conversion experiences elsewhere. Many Malinau stakeholders are also operating under the assumption that greater profits will be generated through converting land to plantation crops, rather than managing these areas under a sustainable timber harvesting regime.

\subsection{THE INCREASING POWER OF EXISTING POLITICAL AND ETHNIC COALITIONS}

Because of the fast pace of change and poor dissemination of information, members of influential commercial and political networks have been generally the first to know about the opportunities created by decentralisation. Many of these individuals have sought to mobilize their resources to take advantage of these opportunities. These have been the people with links to outside trade and government networks, powerful families, and higher levels of education. Most are based in Kota Malinau.

Local communities in some forested areas have not been far behind, however. Village leaders have worked quickly to follow-up on offers from 
logging companies and timber brokers seeking to obtain IPPK permits by entering into various forms of profit-sharing arrangements. In most cases, only a limited number of people, usually village elders, have been involved and benefited from these agreements. The leaders have often not had the information or perhaps influence to negotiate optimal deals for themselves or the communities they claim to represent. Several of the Punan groups in the Malinau basis have suffered the most in this regard. In their enthusiasm to seek even small amounts of income, several leaders have negotiated agreements quickly and have suffered later from weak agreements with the companies in which promises about benefits were never fulfilled. Punan groups have also lost their land in at least two cases and may face more constricted access to forest resources in the future - both because there will be less forests standing and because of the move towards territorializing property rights.

Due to the close-knit nature of relationships between some villages, companies and government officials, coalitions based on family and economic ties have become more influential in allocating favors. Decisions that might be considered technical have become politicized and it has not been uncommon for the members of one office at the district level to fail to attend an official meeting if the members of another office hosted (or even attended) the meeting. Ethnic affiliations appear to have become more divisive than they were before the regional autonomy process began.

The interests of groups not present in Malinaui.e., future generations and groups located at the provincial level and above - have been left unrepresented for the most part in the district decision-making process, raising questions about whether any "public" forest goods will be managed.

\subsection{DECENTRALISATION AS DEMOCRATISATION?}

Decentralisation has given substantial authority and power to district leaders, but the flow of benefits to local populations and their role in decision-making about forests and forest land remains unclear. There is a real risk that decentralisation will result in a (re)concentration of government authority and power at the district level.

The absence of democratic, transparent institutions for deliberation both at the village level and between the village and the kabupaten governments has meant that, the links between government agencies and their constituents have been weak. Almost no district government officials are accountable to district residents through direct elections, open meetings, public records, an independent press and the like. Members of Malinau's DPRD Legislative Assembly are accountable to their parties, not to a geographic constituency, and there are no links between the local village assembly and the DPRD. Adat institutions have lost their credibility for many people, to the point where some villagers are inclined to trust district government decisions more than those of adat leaders. There thus remains no clear way to translate populist interests to district-level policy about forests.

Institutionally, the re-definition of village units and the possibility for working with a strengthened lembaga adat provide opportunities for meaningful participation from the grassroots. Because it is a new district, Malinau also has been able to bring together staff that are largely from the area itself. However, either because of precedent or pressures for expediency, mechanisms for district government consultation and coordination with communities remain to be developed. Two new regulations currently under review (on lembaga adat's relationship with government and on the definition, creation and removal of villages) may make progress on integrating community-level institutions with those of the district 
government. However, because these are based on regulations inherited from Bulungan, they may be structured to allow Malinau's government to take fullest advantage of the potential for reform. ${ }^{79}$ Among Malinau government officials, there appears to be a growing appreciation of the importance of involving communities in decision making, although progress in this area has been hindered by a lack of resources, political will or experience in how to go about securing broader participation. Communities also lack information about their legal rights and possibilities for becoming more involved in district decision-making processes

Although the provisions for adat claims through existing national policies are potentially farreaching, the indirect formalization of adat claims through IPPK licenses has occurred independently of these policies and without systematic criteria or review. . Legally, communities still lack secure rights to land and forest resources and the competition for these resources is only growing. There are no clear criteria or processes for how adat should be defined and conflicts over resources resolved. Also, the benefits from adat claims associated with IPPK's have thus far been skewed, with village leaders and their families receiving a disproportionate share of benefits. The list of benefits promised, however, suggests that companies are seeking to satisfy short-term interests of communities, and communities have been easily attracted by offers of material goods that they have previously considered luxury items, even though the value of these goods is relatively insignificant. Communities have generally lacked information and outside support in negotiating contracts with logging companies and timber brokers. This has often resulted in inequitable agreements that give community members a relatively small share of the value of logs harvested and weak guarantees that the timber company will meet its obligations. The lack of enforceability of the IPPK contracts has, in many cases, meant that logging companies have been able to exploit timber without providing the promised benefits to communities. 


\section{ENDNOTES}

${ }^{1}$ It is, perhaps, important to note that it is not only upriver peoples who must endure the logistical challenges associated with fragmented manner in which the new kabupatens have been organized. One informant in Malinau noted, for instance, that if the Bupati of Nunukan wants to visit his kabupaten's subdistrict of Krayan, he must first travel to Tarakan. Although he can catch a MAF flight from Tarakan to Krayan, the flight stops in Malinau along the way. By the same token, much of the area within Kabupaten Malinau is not accessible by air travel and cannot yet be reached by road.

${ }^{2}$ According to Bupati Marthin Billa, some HPH timber concessions that extend into Malinau's Kayan Hulu sub-district are also regulated by CDK Kutai Barat, as their operations are based in Kutai. CDK Kutai Barat, however, does not have formal jurisdiction over forestry activities in any of Malinau's subdistricts, as have CDK Bulungan Tengah and CDK Bulungan Selatan. ${ }^{3}$ It should be noted that not all of the HPH concession areas listed in Table 4 are fully located within Malinau's district boundaries. Some of them overlap substantially with the neighboring kabupatens of Bulungan and Nunukan.

${ }^{4}$ Interview with sawmill owner, Malinau, September 9, 2000.

${ }^{5}$ Personal communication, Malinau, May 2, 2001.

${ }^{6}$ Interview with official at Dinas Pendapatan Daerah, Malinau, September 6, 2000.

${ }^{7}$ Interview with officials at Inhutani II, Malinau, September 8, 2000.

${ }^{8}$ Interview with officials at Inhutani II, Malinau, September 8, 2000.
${ }^{9}$ Interview with officials at Inhutani II, Malinau, September 8, 2000.

${ }^{10}$ Personal communication from Marthin Billa, Malinau, May 2, 2001.

${ }^{11}$ Keputusan Gubernur Kalimantan Timur Nomor 20 Tahun 2000, tentang Penetapan Dana Kompensasi Kepada Masyarakat Didalam dan Sekitar Hutan di Propinsi Kalimantan Timur, dated June 9, 2001.

12 These amounts were reported by knowledgeable informants in Malinau. However, they are substantially higher than the amounts specified in SK No 20/2000, which prescribes that companies pay Rp 1,500 per m3 of meranti/kayu indah harvested during April 1995 - March 2000, and Rp 3,000 per m3 harvested after April 1, 2000. The reason for this discrepancy is not clear.

${ }^{13}$ Interview with Sekretaris Inspektorat Wilayah, Malinau, September 7, 2000.

${ }^{14}$ Interview with head of Bagian Sosial Ekonomi, Kantor Bupati, Malinau, September $10,2000$.

${ }^{15}$ Interview with Unit Manager of Inhutani II, Malinau,

${ }^{16}$ Interview with Manager of PT Comismar, Tarakan, March 252000.

${ }_{17}$ Interview with timber broker, Malinau, September 9, 2000.

${ }_{18}$ Interview with Manager of PT Comismar, Tarakan, March 25, 2000. This individual claimed that he had gone to Malinau looking for land that would be suitable for oil palm, but was only able to find small parcels. He indicated that a minimum of 7,000 ha is needed for new oil palm plantations, and that the committee that reviews HGU (Hak Guna Usaha) land 
utilization applications in Samarinda will not grant permits for areas less than this. HGU permits, moreover, are required to have 100 percent clearance from other land-owners. The informant reported that in Malinau, 'it appears that third parties are going through villages to tie up land in anticipation of investors.'

${ }^{19}$ The informant reported that such payments often went into the private bank accounts of government officials, yet the company would still receive an official receipt. In one case, he recalled, company officials went to a bank with an official to make a payment of Rp 68 trillion, which the official insisted be paid in cash. Upon receiving the payment, the official immediately took the money to his own bank. The company received an official receipt for the full amount paid.

${ }^{20}$ Interview with head of Dinas Pekerjaan Umum, Malinau, September 9, 2000. The head of Malinau's Public Works office indicated that they plan to develop a shallow port near the bridge in Kota Malinau, which would be used for small boats; and to construct a deep-water port downriver from the town, which would allow 100-tonne vessels to enter the area.

${ }^{21}$ Malinau officials have also reported that they are considering the construction of a road linking the Kayan Hulu region to Sarawak, and are encouraging their counterparts in Kabupaten Nunukan to support the development of a road that would link the Town of Malinau to Sabah. One informant noted that these roads would play an important function in enabling heavy equipment to be brought into the region.

${ }^{22}$ Interview with head of Bappeda, Malinau, March 26, 2000.

${ }^{23}$ Keputusan Bupati Kabupaten Bulungan Nomor 19 Tahun 1999, tentang Tata Cara Pemberian Ijin Pemungutan dan Pemanfaatan Kayu Pada Hutan Rakyat dan Hutan Milik, dated July 28, 1999.

${ }^{24}$ It should be noted that the legal genealogy of the IPPK permits issued by Malinau's district government is, in fact, rather sketchy. Many of the IPPK permits signed by the Bupati do not cite the Bulungan Bupati's Decision No 19/1999. Moreover, many of these permits mistakenly cite
Government Regulation No 62/1998 as Government Regulation No 63/1998. Within the permits themselves, several clauses refer to the license being granted as 'Ijin Pemanfaatan Kayu (IPK)' rather than 'Ijin Pemungutan dan Pemanfaatan Kayu', or IPPK. This conflation of the IPPK permits with IPK permits reflects the common practice among Malinau government officials, industry actors, and community members to refer to the new permits as IPKs or small-scale IPKs ('IPK skala kecil'). In fact, Ijin Pemanfaatan Kayu, or IPK, is a license for timber removal on forest areas slated for conversion, which only the Ministry of Forestry has the authority to allocate.

${ }^{25}$ Notably, Decision No 19/1999 issued by the Bupati of Bulungan makes no reference to PP No 6/1999 regarding forestry enterprises and the extraction of forest products in areas designated as Production Forest, which was issued on January 27, 1999. Among other things, PP No 6/1999 gave authority to district governments to issue permits known as HPHH (Hak Pengusahaan Hasil Hutan, or Forest Product Concession), which allow the extraction of timber and/or nontimber forest products in areas of 100 ha that are located within the governmentcontrolled Forestry Estate (Kawasan Hutan). The process for allocating HPHHs was further elaborated in Ministerial Decision No 310/1999. (See the chapter on decentralization in Berau for further details).

${ }^{26}$ Government Regulation of the Republic of Indonesia Number 62, Year 1998 Concerning Delegation of Part of Government's Affairs in the Sector of Forestry to the Region.

${ }^{27}$ Informal reports suggest that by May 2001, the number of IPPKs issued in Kabupaten Bulungan had reached 300 and that these cover an aggregate area of 30,000 ha. These data have yet not been confirmed.

${ }^{28}$ In cases where the IPPK permit has been issued for an area larger than the legal limit of 100 ha, the Bupati's Decision assigning the IPPK specifies that the area has been divided into 100 ha parcels, each of which is associated with a specific individual or family from the collaborating community. 
${ }^{29}$ Surat Keputusan Bupati Kabupaten Malinau Nomor 16 Tahun 1999, tentang Penerimaan Suumbangan Pihak Ketiga Kepada Pemerintah Kabupaten Malinau dan Tata Cara Pemberian dan Penerimaam Sumbangan.

${ }^{30}$ Interview with timber broker, Malinau, September 9, 2000.

${ }^{31}$ Interview with timber broker, Malinau, May 2, 2001.

${ }^{32}$ It should be noted, however, that Bupati Marthin Billa indicated in early-May 2001 that he has suspended the issuance of new IPPK permits in order to allow time for the district government to evaluate the impacts of the IPPK permits issued thus far.

${ }^{33}$ Interview with CDK official, Malinau, September 9, 2000.

${ }^{34}$ Interview with Inhutani I officials, Malinau, September 9, 2000. These officials argued that most of the companies receiving IPPK permits appear to be 'fly-by-night' companies. One sign of this, they claimed is the fact that most IPPKrecipients are registered as CVs (Commanditair Vennootschap, or Limited Partnerships) rather than PTs (Perseroan Terbatas, or Limited Liability Companies). As they explained the difference between the two classes of companies, CVs are generally registered only with a notary and not at the Department of Justice; are individually owned and do not have a Board of Directors; and can only be held liable for the value of their assets. PTs, on the other hand, are more tightly regulated and their owners are personally liable for the activities of the company.

${ }^{35}$ Interview with Inhutani I officials, Tarakan, September 12, 2000.

${ }^{36}$ The officials explained that Inhutani is assigned an annual quota for petrol, and is required to order its fuel a full year in advance, for which it deposits a cash bond at a regional bank. The large numbers of new heavy equipment coming into the region triggered a shortage of fuel in mid-2000, leading to demonstrations at Pertamina and long lines.

${ }^{37}$ Interview with Inhutani I officials, Tarakan, September 12, 2000.

${ }^{38}$ Interview with Inhutani I officials, Malinau, September 9, 2000.
${ }^{39}$ Interview with official at Kantor Bea Cukai, Tarakan, September 13, 2000. According to the regulations governing this category of imports, the importer is required to register the purpose of the equipment; the location where it will be used; and the length of time that it will be in Indonesia before being 're-exported.' The importer is not allowed to move the equipment from the registered location, without approval from the Customs office. Moreover, the importer is required to post a cash bond to guarantee that the equipment will be sent out of Indonesia at the end of the permit period.

${ }^{40}$ In several cases, the timber brokers are also traders in rotan, gaharu, damar, and other nontimber forest products. Many of these individuals have long-standing ties to forestbased communities engaged in collecting these products. It is often the case that households within such communities are heavily indebted to the NTFP traders, and there is a strong likelihood that debt relations of this sort have shaped the agreements made between the brokers and communities regarding IPPK timber extraction.

${ }^{41}$ For instance, the local timber broker who arranged CV Hanura's IPPK permits within Inhutani II's HPH concession boundaries (see below) served as the local treasurer for the government-controlled political party, GOLKAR, during 1993-1998. He also sat on the committee that oversaw the selection of DPRD members.

${ }^{42}$ Interview with timber broker, Malinau, September 9, 2000.

${ }^{43}$ Interview with Sekretaris Daerah, Malinau, September 11, 2000.

${ }^{44}$ Interview with timber broker, Malinau, September 7, 2000. Among industry observers in Malinau, there is considerable speculation that payments for signatures on IPPK permits may, in fact, have been much higher than the amount acknowledged by the timber brokers interviewed.

45 Keputusan Menteri Kehutanan dan Perkebunan Nomor 310/KPTS-II/1999, Tentang Pedoman Pemberian Hak Pemungutan Hasil Hutan, dated May 7, 1999. 
46 Keputusan Menteri Kehutanan dan Perkebunan Nomor 317/KPTS-II/1999, Tentang Hak Pemungutan Hasil Hutan Masyarakat Hukum Adat Pada Areal Hutan Produksi, dated May 7, 1999.

${ }^{47}$ Through August 2000, when this interview was conducted, the Bupati of Kutai Induk had reportedly issued over $260 \mathrm{HPHHs}$, many of which were located in areas being managed by HPH timber concessionaires.

${ }^{48}$ Interview with Sekretaris Inspektorat Wilayah, Malinau, September 7, 2000.

49 Interview with timber broker, September 7 , 2000.

${ }^{50}$ Interview with Inhutani I officials, Malinau, September 12, 2000.

${ }^{51}$ Interview with timber broker, Malinau, September 10, 2000.

${ }^{52}$ Interview with timber broker, Malinau, September 9, 2000.

${ }^{53}$ Interview with Sekretaris Daerah, Malinau, September 11, 2000.

${ }^{54}$ Interview with Sekretaris Inspektorat Wilayah, Malinau, September 7, 2000.

${ }^{55}$ Interview with Inhutani I officials, Malinau, September 12, 2000.

${ }^{56}$ Surat Direktur Jendral Pengusahaan Hutan Produksi Nomor 1563/Menhutbun-VI/1999, mengenai Penundaan Keputusan Bupati KDH Tk II Bulungan No 19 Tahun 1999, Tanggal 30 September 1999.

${ }^{57}$ Surat Gubernur Propinsi Kalimantan Timur Nomor 521/12788/Proda.2.2/EK, Tanggal 10 November 1999.

${ }^{58}$ Surat Menteri Kehutanan dan Perkebunan Nomor 603/Menhutbun-VIII/2000, mengenai Penghentian/Penangguhan Pelepasan Kawasan Hutan, Tanggal 22 Mei, 2000.

${ }^{59}$ Interview with officials at Inhutani I, Tarakan, September 13, 2000.

${ }^{60}$ Interview with unit manager at Inhutani II, Malinau, September 8, 2000.

${ }^{61}$ Interview with unit manager at Inhutani II, Malinau, September 8, 2000.

${ }^{62}$ Interview with officials at Inhutani I, Tarakan, September 13, 2000.

${ }^{63}$ Interview with unit manager at Inhutani II, Malinau, September 8, 2000.
${ }^{64}$ Interview with officials at Inhutani I, Tarakan, September 13, 2000.

${ }^{65}$ In Kabupaten Bulungan, it appears that the Inhutani's and other HPH-holders may have an added incentive to enter into such profit-sharing arrangements with IPPK-holders: In January 2001, the DPRD considered a draft Perda which would allow the Bupati to issue export permits for logs harvested under IPPK permits allocated by the district government. It is not clear whether this Perda has been approved in Bulungan or if the district government in Malinau is considering similar legislation. If such a regulation were to be introduced, this would enable IPPK-holders to legally export $\operatorname{logs}$ to Malaysia without needing to obtain an export license from Jakarta. Although the national government legalized log exports in 1998 in response to pressure from the IMF, the Ministry of Industry and Trade has since issued export permits for only a relatively small volume of logs. There are indications that the Ministry of Forestry has been reluctant to support large-scale timber exports from Indonesia and, in any case, would be highly unlikely to provide supporting recommendations for the export of $\log s$ harvested under IPPK permits issued by district governments.

${ }^{66}$ Four additional rules, common elsewhere in Kalimantan, further guided rights to forest resources. First, a person who cleared an agricultural field from primary forest automatically obtained ownership66 of that plot. Second, a person could borrow a plot of secondary vegetation from a fellow villager for one rice season, but was not allowed to plant trees. Third, the planting of trees was taken as a sign of ownership, being associated with regular use of the land over time and proof of continued interest in the plot. People often refer to fruit trees as their "land certificate" (segel). Fourth, hunting and the collection of fallen fruit or wild species was permitted across territories, although it was considered polite to request permission from the village head before entering another group's territory.

${ }^{67}$ WWF-Indonesia Program worked from 1990 to 1996 to convert the status of the area from a 
nature reserve (cagar alam) to national park (taman nasional), with the later status granting resident communities the rights to consumptive use of resources within specified zones of the park. They also have worked to encourage local people to identify where these zones should be and to develop a stewardship approach to the forest more generally.

${ }^{68}$ Which began in 1994 before decentraliation policies took place.

${ }^{69}$ This decree was based on a provision in the 1999 basic forestry law (UU No 41/1999) that requires companies to pay compensation to communities.

${ }^{70}$ The only criteria currently available are those listed in UU No 41/1999.

${ }^{71}$ This fairly recent policy was adopted in boilerplate fashion across Indonesia in response to Peraturan Menteri Dalam Negeri No. 3/1997 and states that wilayah adat adalah wilayah satuan budaya tempat adat istiadat itu tumbuh, hidup dan berkembang, sehinga menjadi penyangga keberadaan adat istiadat yang bersangkutan.'

${ }^{72}$ Although initially the Punan wanted a separate territory but due to a subsequent uneven division of the territory, they settled for a joint village territory.

${ }^{73}$ Rights to these enclaves were often derived from historical agreements.

${ }^{74}$ In interviews with local communities in the Malinau area, there was relatively little interest in the development of oil palm. Several sources indicated that Malinau communities and officials, alike, are deeply skeptical about the prospects for oil palm development, given that many estate crop companies in neighboring Bulungan district never planted their concession areas after clearing the timber from them.

${ }^{75}$ The wife of the owner of C.V. Hanura originated from the village of Batu Kajang, as did the wife of one of the staff members of C.V. Putra Surip Wijaya.

${ }^{76} \mathrm{He}$ is presently head of the Malinau Legislative Assembly (DPRD Malinau),
${ }^{77}$ Langap could be included in this list as well because of their efforts to claim the entire upper watershed as part of the Merap adat area.

${ }^{78}$ Relatively few NGO's or other organisations are active in this area. The only NGO with an ongoing presence is Yayasan Adat Punan, based in Kota Malinau. This foundation aims at assisting the development of the Punan communities through formal and non-formal education, however it faces problems of co-ordinating and visiting its constituency due to the large area over which the Punan communities are scattered and the lack of financial means. The more accessible communities have been visited more often (e.g., Bila Bekayuk and Mirau/Halanga). The position/ strategy of the Yayasan Adat Punan seems to be to try to obtain full control by the Punan communities over their territories and the resources found in it. This is especially the case for the Tubu area, which is (regarded as) an exclusively Punan area. That approach might not always provide the expected result e.g. in the case of Setarap when the Punan community requested a separate village area they were assigned a very small part of the village area. It will be interesting to see in how far the new arrangement of equal rights for everybody in the village will work out. In the case of Bila Bekayuk the Punan actually sold of their part of the combined Long Loreh village territory before it was eventually divided.

${ }^{79}$ For example, the adat regulation indicates that government should control how adat is defined and sanctioned. This control is to be exercised in a hierarchical fashion from the district downwards, yet the regulation is vague however about whether a relationship exists at all between village government and adat institutions. Should government regulate the recognition of adat to ensure fairness and possible conflicts? Some local people think so given the uncontrolled nature of adat claims to date. Others think adat is weakened and no longer genuine to the extent it is merged with government 


\section{References}

Ascher, W. 1995. Communities and sustainable forestry in developing countries. ICS Press, San Francisco.

Asosiasi Pengusaha Hutan Indonesia (APHI). 2000. Catatan Hasil Rapat, Unpublished document. June 29, 2000.

Bagian Perekonomian Sekretariat Kabupaten Bulungan. 2000. Rekapitulasi Ijin Pemungutan dan Pemanfaatan Hutan Rakyat Yang Dikeluarkan Oleh Bupati Kab. Bulungan. Unpublished data. September 15.

Bappeda Tk II Bulungan and Kantor Statistik Kabupaten Bulungan. 1998. Ikhtisar Statistik Kabupaten Bulungan 1997. CV Krama Agung, Samarinda.

Barber, C. V., Johnson, N., \& Hafild, E. 1994. Breaking the log jam: Obstacles to forest policy reform in Indonesia and the United States. World Resources Institute, Washington, DC.

Barr, C. 2001. Banking on sustainability: Structural adjustment and forestry reform in Post-Suharto Indonesia. Center for International Forestry Research and WWF Macroeconomics Program Office, Washington, DC.

Barr, C. and Resosudarmo, I. A. P. 2001. Decentralisation and forest administration in Indonesia: Implications for forest sustainability, community livelihoods and economic development. Draft. Center for International Forestry Research, Bogor, Indonesia.

Brandon, K. E. and Wells, M. 1992. Planning for people and parks: Design dilemmas, World Development 20 (4): 557-70.

Carney, D. 1995. Management and supply in agriculture and natural resources: Is decentralisation the answer? Overseas
Development Institute Natural Resources Perspectives No. 4. Overseas Development Institute, London.

Conyers, D. 1981. Decentralisation for regional development: A comparative study of Tanzania, Zambia and Papua New Guinea, Public Administration and Development I (2): 107-20.

Dinas Kehutanan .1999. Dinas Kehutanan Dalam Angka Tahun 1998/1999. Pemerintah Propinsi Daerah Tingkat I Kalimantan Timur, Samarinda.

Indonesia-UK Tropical Forest Management Programme (ITFMP). 1999. Illegal logging in Indonesia. Report No. PFM/EC/99/03, Jakarta.

Kantor Wilayah Propinsi Kalimantan Timur (Kanwil Kaltim). 1998. Pemutahiran Data Pengusahaan Hutan Tahun 1997/1998. Departemen Kehutanan dan Perkebunan, Samarinda.

Ostrom, E. 1990. Governing the commons: The evolution of institution for collective action. Cambridge University Press, Cambridge.

Rivera, R. 1996. Decentralización y gestión local en América Latina. FLASCO, San Jose.

Rondinelli, D., Nellis, J. R., and Cheema, G. S. 1983. Decentralization in developing countries: A review of recent experience. Staff Working Papers No. 581. World Bank, Washington, DC.

Scotland, N., Fraser, A., and Jewell, N. 1999. Roundwood supply and demand in the forest sector in Indonesia. Indonesia-UK Tropical Forest Management Programme, Report No. PFM/EC/99/08 (November 23 ${ }^{\text {rd }}$ draft). Jakarta, Indonesia.

Sekretaris Daerah Kabupaten Malinau (Sekda Malinau). 2001. Paparan: Potensi dan 
Pandangan Kabupaten Malinau. Unpublished document.Toha, M. 2000. Unpublished paper.

Suara Kaltim. 2000a. Daerah Lintas Batas dan Rawan Penyulundupan. November 1.

Suara Kaltim. 2000b. Utara Pisah dari Kaltim

Tinggal Tunggu Waktu Saja. November 2.

Sunderlin, W. D., Resosudarmo, I. A.P., Rianto,

E. and Angelsen, A. 2000. The effect of

Indonesia's economic crisis on small farmers and natural forest cover in the Outer Islands.

Occasional Paper No 28 (E), Center for International Forestry Research, Bogor, Indonesia.

Tim Peneliti Pemekaran Wilayah Tingkat I Kalimantan Timur. 1999. Laporan: Hasil Study Pemekaran Wilayah Kabupaten Daerah Tingkat II Bulungan, Propinsi Dati I Kalimantan Timur. Estimated deforestation rate for Indonesia. Unpublished presentation prepared for the CGI seminar on Indonesian Forestry, Jakarta. January 26.

Usher, G. 2000. Discussion paper on: Why donors should concentrate their programs at the kabupaten level, or why focusing donor support at the kabupaten level is more likely to achieve better natural resource management. East Kalimantan NRM Program.

Utting, P. 1993. Trees, people and power: Social dimensions of deforestation and forest protection in Central America. Earthscan, London.

World Bank. 2001. Indonesia: Environment and natural resource management in a time of transition. World Bank, Washington, DC. 